University of Louisville

ThinkIR: The University of Louisville's Institutional Repository

Electronic Theses and Dissertations

6-1943

\title{
A study of day care particularly in reference to Louisville, Kentucky.
}

Nancy Lee Johnson

University of Louisville

Follow this and additional works at: https://ir.library.louisville.edu/etd

Part of the Social Welfare Commons

\section{Recommended Citation}

Johnson, Nancy Lee, "A study of day care particularly in reference to Louisville, Kentucky." (1943). Electronic Theses and Dissertations. Paper 1983.

https://doi.org/10.18297/etd/1983

This Master's Thesis is brought to you for free and open access by ThinkIR: The University of Louisville's Institutional Repository. It has been accepted for inclusion in Electronic Theses and Dissertations by an authorized administrator of ThinkIR: The University of Louisville's Institutional Repository. This title appears here courtesy of the author, who has retained all other copyrights. For more information, please contact thinkir@louisville.edu. 
UNIVERSITY OF LOUISVILLE

\author{
A STUDY OF DAY CARE \\ PARTICUIARLY IN REFERENCE TO \\ LOUISVIIJE, KENTUCKY
}

\begin{abstract}
A Dissertation
Submitted to the Feculty

of the Graduate Division of Social Administration

In Partial Fulfillment of the

Requirements for the Degree

or Master of Science in Social Administration
\end{abstract}

\author{
Graduate Division of Social Administration \\ By \\ Nancy Lee Johnson \\ Year \\ 1943
}


NAME OF STUDENT: Nanoy Lee Johnson

TITLE OF THESIS: A Study of Day Care Particularly In Reference to Louisvilie, Kentucky.

APPROVED BY RAADING COMMITTEE COMPOSED OF THE

FOLLOWING MEMBERS:

John J. Cronin

NAME OF DIRECTOR: John J, Cronin

DATE: fume 5,1943 
$\frac{1}{2}$

()

ख

ACKNOWLEDG HERTS

«

The author gratefully ackmowledges the assistance of the following:

Mr. John J. Cronin

Miss Geraldine B. Graham

Mr. Brnest Greenwood

Miss Ethel C. Dupont

Mrs. Albert Sawyer

62550 
TABLE OF CONTENTS

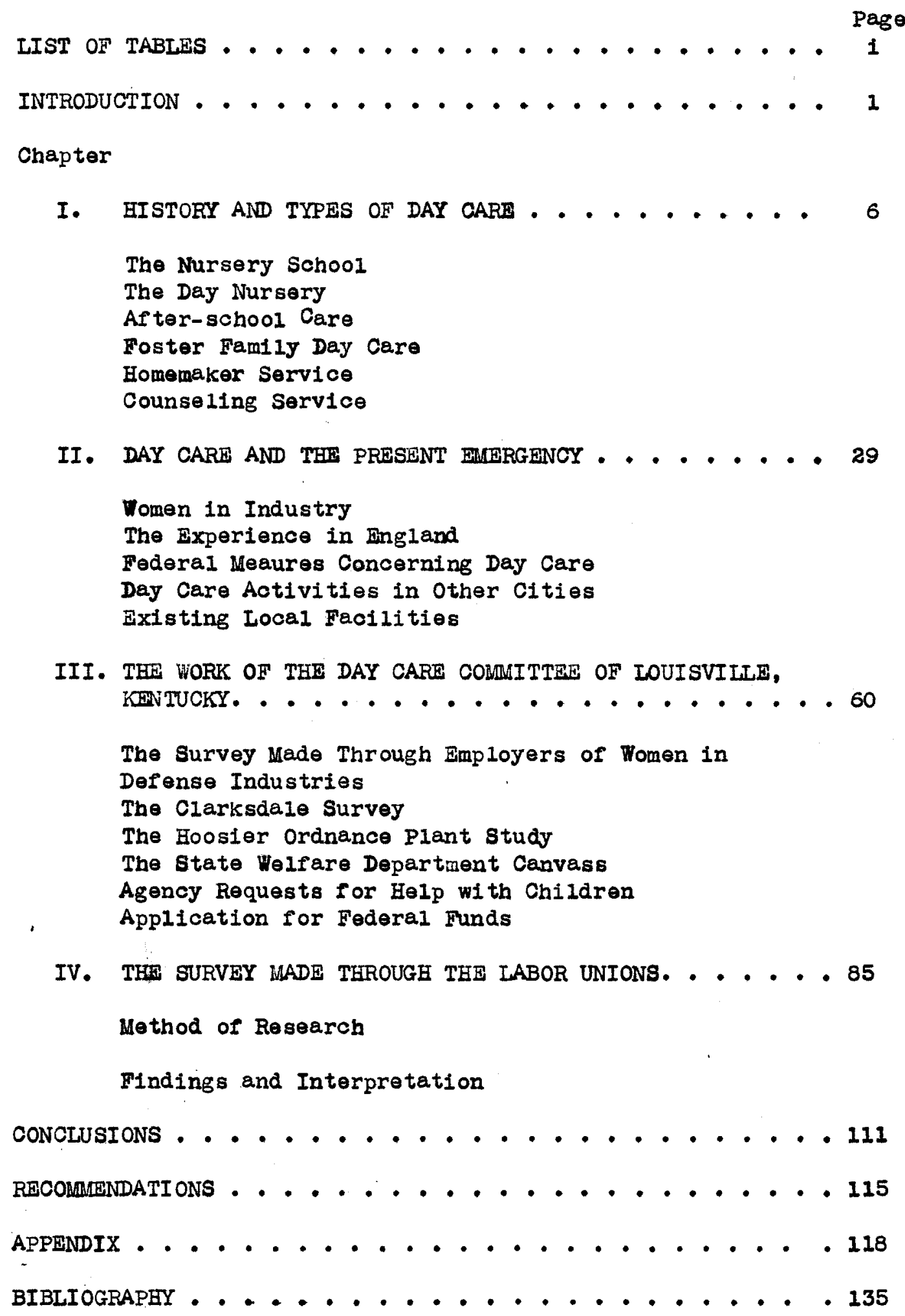


1. Louisville Mothers Responding to the Day Nursery Questionnaire at the Hoosier Ordnance Plant, According to the Number of Children Two Years 01d and Over in the Family ....... 70

2. Louisville Mothers Responaing to the Day Nursery questionnaire at the Hoosier Ordnance Plent, According to the Mother's Working Shift ...... 70

3. Ohildren Two Years Old and over Reported by Louisville Mothers Answering the Day Nursery Questionnaire at the Hoosier Ordnance Plant, According to the Ages of the Children ..... 71

4. Louisville Mothers, Answering the Day Nursery Questionnaire at the Eoosier Ordnance Plant, Reporting Absences from Work, According to the Number of Children Two Years 01d and over in the Family ............. 71

5. Louisville Mothers, Answering the Day Nursery Questionnaire at the Hoosier Ordnance Plant, Reporting Absences from Work, According to the Family and According to the Mother's shift . . . . 72

6. Louisville Mothers, Answering the Day Nursery Questionnaire at the Hoosier ordnance Plant, Reporting Absences for Work, According to the Ages of Their Children Two Years 01d and over.... 72 
INTRODUCTION 


\section{Introduction}

A problem of great concern to many communities in the United States is that of day care of children of working mothers. Since the beginning of the defense program and particulariy after the United States entered the war, wide publicity has been given to the problem of children left without supervision while their mothers worked. Communities that were affected by Increases in population began to establish committees to cope with the situation. Numerous surveys were conducted in an attempt to measure the adequacy of existing facilities and the extent of the need for additional day care centers.

Congressional action made federal funds available to $100 a 1 \mathrm{com}-$ munities when the Lanham Aot was approved on May 28, 1941. This was the revised act of October 14, 1940, to "expedite the provision of housing in connection with national defense, and for other purposes." Representative Lanham stated in the House, "by reason of the great influx of population into some localities. - . large sums of money were appropriated and are being used for defense housing. Necessarily the action which has been taken has resulted and is resulting in congested areas which force upon the local communities problems they are unable to solve and involve amounts of money they are not able to expend." Iittle mention was made in the Congressional hearings of day care, as interest was centered primarily in the immediate and tangible needs for schools, waterworks, hospitals, recreational facilities and roads. 1

${ }^{1}$ HR 4545, Congressional Record, Vo1. 87, Part IV, (Washington: Government Printing office, 1941) p. 3852 
The reason for the necessity to determine the need for day care is contained in a statement made by Representative lincGregor in a Congressional hearing, "I want to impress on the minds of the Members that first, before you are to receive any of the money, you have to show a defintte need." It was made clear, however, that the local community did not have to exhaust all its tax resources before it would be able to qual1fy. 2

It was found in community after community that studies of the need for day care falled to show the need. This may be partly explained by the fact that in spite of the long history of nurgery schools, creches, and day centers in Burope, the provision of group oare for children under kindergarten age in the United States is a comparatively recent innovation. Educators, social workers and others interested in the welfare of the family have made every effort to make it possible for mothers to stay in the home and have frowned, more or 1ess, on women who did not need to work, but who preferred to be employed. Only in very recent years has it been recognized that it is often better for children to learn how to adjust to a group before they enter kindergarten or school than to be subjected to the overprotection they sometimes get at home. More approval has been shown of the methods of day care since there have been indications that women were needed in industry to help win the war.

The present war emergency has greatly accelerated progress in the day care field. Standards for day care programs that will provide training for children up to eighteen years of age have been established. The whole question of the relationship between women in industry and the actual

\footnotetext{
I Ibid. , p. 3860

2

Ibid., p. 3857
} 
need for them to work has been analyzed. At the same time the nursery school experience has been tested both in this country and in England. England's experience has been helpful to the United states even though the problem was not always identical in the two countries.

The present war emergenoy has also provided the Impetus for many communities to evaluate their resources in terms of day care. In spite of Louisville's fairly long history of nursery schools and day centers, little community interest or studied planning was evident until the establishment of the Day Care Committee. This represented a concerted attempt on the part of a lay and professional group to discover the scope of the 10cal problem of day care and institute action to meet the community's needs.

It was found that the oldest day care centers in Louisville were located near the center of town, necessitating long trips by many mothers to take their children to the centers. The WPA provided several that were not in the immediate central business district, but the majortty of them were near the central area and no facilities were available for children In the outlying residential districts other than the private schools which do not serve the 10w-income groups. As in geographical planning, there was little community interest in malntaining standards that were recommended by state and federal agencies. The principal nursery for Negro children is at the present time realizing only a fraction of its potent1alities, although many improvements have been made in the last decade. This study includes a brief history of day care, its role in the present day wartime picture, and an account of the efforts that have been made to investigate the need for day care in Louisvilie. The study 
through the labor unions was made by the author. The situation is constantly changing; statistics that were valid in one month may be worthless the next.

Materlal was secured through the United States Children's Bureau, the Day Care Committee minutes and surveys, correspondence with agencies and individuals in many localities throughout the United States, and the published 11terature on the subject. The author spent several months at the Mental Hygiene Clinic of this city which operates a nursery school for children with behavior problems. This school has received national acclaim for its advanced methods. The experience proved to be valuable in that many of the standards maintained in the school served as criteria in evaluation of the total day care system. 
CEAPTBR I

HISTORY AND TYPES OF DAY CARE 


\section{Chapter I}

The Nursery School

The nursery school dates back to ancient times when the institution was known to the Jews. The Romans provided a ludus, or play place, for their young children, and although there may not be a striking similarity between the modern nursery school and the one in Comenius' School of the Hother's Knee, the goals and atmosphere of the two resemble each other in no small degree. 1

Schools for children of working mothers were organized first in England by philanthropists in the early part of the nineteenth century. Robert Owen, owner of a large cotton mill in the industrial village of New Lanark, Scotland, was a pioneer in the development of care of children of pre-school age. He believed that "environment makes the man" and began h1s Infant School that was designed to provide a "rational training for infants from one to six years of age." Music and singing were among its activities and the methods of discipline were practiced with kindness. Unfortunately many of the schools that were modeled after his in Ingland became little more than training centers in social conformity. 2

On the Continent, Jean Frederic Oberlin, a Lutheran minister, thought that physical care for the babies or working mothers could be combined with inculcating desirable social habits in the children.

${ }^{1}$ J.C. Foster and M.I.Mattson, Nursery School Procedure

(New York: D. Appleton and Co., 1929), Introduction, p. VII.

2I1se Forest, The School for the Child from Two to Eight

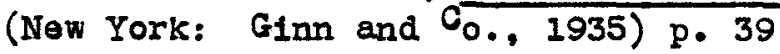


His work in France was followed by the establishment of salles diasiles supported by philanthropic women and a wealthy lawyer, Cochin. The educational methods resembled closely those that are used today. Oberlin maintained that rich children had a tendency to be spoiled at home and that they needed nursery school training as much as the children of the poor.

In 1833 the salles diasiles were incorporated into the French national school system and fifteen years later the name was changed to ecoles maternelies, as the emphasis shifted to the educational aspect from the philanthropic interest. From all indications they were more spontaneous than the later British schools. Italy's infant schools were set up in the third decade of the nineteenth century in certain large cities. Germany and Belgium Iikewise cared for the children of the poor, with concern focused on the child's physical welfare and protection from injury. 1

Thus a precedent was set for the modern nursery school movement which began w1th the work done by Miss largaret Molilian, and her sister, Miss Rachel MoMilian in England in 1908. The fact that many British school children were found about this time on examination to be physically inferior aroused the indignation of the people. They came to the conclusion that much preventive work could be done before the children started to school. Therefore the instilling of good hyglenic habits became one of the chief aims of the Misses Mollilan in their nursery for children of poor parents. 2

\footnotetext{
I Ibid. , p. 40

Ibid., p. 41
} 
War conditions gave greater impetus to the nursery school movement in England. Many mothers were employed in munitions plants and needed care for their children. Data compiled from war hospitals indicated that more than a few nouroses and psychoses in soldiers could be traced back to childhood difficulties.

In 1918 the famous Fisher Act was passed. This permitted the inclusion of the nursery schools in the public school system. By this act "nursery schools that are inspected and to a certain extent controlled by the local education authorities receive sums equal to half their net expenditures in the forms of grants in-aid from parliament." By 1923 there were listed 26 recognized nursery schools, all of wh1ch were inspected regularly and received grants in aid. ${ }^{1}$ In the two decades following the passage of the Fisher Act, there gradually beceme available to almost every local authority child welfare clinics, school medical services, district nursing services, trained health visitors and trained midwives. 2

The United States also saw a rapid development of nursery schools after the World War. They emerged here largely as research Institutions supported by universities interested in child behavior and development, but there were also other avenues of progress. The research center nursery school was first organized at certaln large schools so that workers in psychology, psychlatry, medicine, and nutrition might observe normal children. These came about partiy because of the growing emphesis

${ }^{1}$ White House Conference on Child Health and Protection Nursery Education, Section III Education and Training (New York: The Century Cb.. 1931) p.9

2 Martha Eliot, Civil Defense Measures for the Protection of Chilaren (Washington: Government Printing office, 1942) p. 165. 
on preventive medicine. Examples of the most elaborate setups are located at the Institution of Human Relations at Yale and the Universities of Iowa, Minnesota, and Columbia.

The cooperative nursery school became quite popular during the first World War when many mothers were going to work for the first time. Small groups of parents were organized with the plan of different mothers alternating in caring for the children. This method proved unsatisfactory with the result that parents became convinced that a trained teacher was necessary, 1 and assistants whose number dependa on the amount of service given by each mother. The cooperative nursery school at the University of Chicago is one of the oldest and best examples of this type. 2

The private nursery school has variable standards; the majority of them are established for profit to the director or teacher. They are found in many suburban districts and cities and are patronfzed by much the same economic class of people who patronize other private schools. 3 The philanthropic or social service nursery school is of ten found in settlements or in connection with orphans' homes, or in other institutions concerned with those in the low income groups. 4

The teacher-tralning sohool provides opportunity for the beginning teacher to learn nursery school procedure. There has been much disagreement over standards for nursery school teachers. A survey made in 1941 revealed that there were 331 nursery school directors, 132 of whom held their Bachelor of Arts degrees, 75 held Master of Arts degrees, and

IIse Forest, The School for the Child from Two to Bight (New York: Ginn and C.., 1935) p. 45

${ }^{2}$ J. C. Foster and M. I. Mattson, Nursery School Procedure (New York: D. Appleton and Co., 1929) p. 10

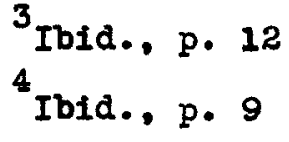


6 had the degree of $\mathrm{Ph}$. D. This shows the contrast to the course offered in England where training approximates our typical normal-training courses for kindergarten teachers. One reason for this is that in America the director is expected to be a qualified leader of parents as well as children. 1

The behavior problem nursery schools fall into two general categories: "Those which take cases referred to them solely for the child himself and those which combine their service to the child with a demonstration center for the illustration of the handling of different types or problems." The teacher in charge should have some psychiatric training and ordinarily this type of school needs more teachers per school than any of the above mentioned. More staff conferences are also considered advisable, than in any of the other set-ups. 2

These various types of schools under private and public auspices sprang up throughout the country in the years between 1918 and 1933. They varied according to basis for adminsion, fees, means of transportation, hours during which they were open, amount of equipment, method of direction and requirements in training for teachers. In December, 1933, $\$ 2,000,000$ a month was grented for unemployed teachers through the Pederal Bmergency Relief Administration. Thirty-one states took advantage of the FERA grant, 61,000 children were enrolled and 4,000 unemployed teachers and others were given employment. The FERA schools were a move in the direction to Incorporate nursery schools into the governmental system. 3

IIse Forest, The School for the Child from Two to Eight, (New York: Ginn and $\left.C_{0 .}, 1935\right)$ p. 55.

2. C. Foster and M. L. Mattson, Nursery Bchool Procedure (New York: D. Appleton and Co., 1929) p. 10

3 Ilse Forest, The School for the Child from swo to Bight, (New York: Ginn and Co., 1935) p. 65 
The Day Nursery

The modern day nursery is descended from the French creche, the first of which originated in paris in 1844 for the care of children of working mothers. Creches became so numerous by 1862 that an Imperial decree was issued which set forth rules for them to follow in the event that government funds might be obtained. It was there that the day nurseries developed into institutions serving as centers for lowering the Infant death rate and teaching hygiene to parents. 1 From France the idea spread to other countries with the result that today in most Buropean countries the day nursery, creche, or similar institution is under governmental auspices and support. 2

The first day nursery in the United States was opened in New York City in 1854. This was followed in 1858 by one in Troy, N. Y., and one in Philadelphia in 1863. By 1892 there were 90 organized day nurseries found in this country; 175 were in existence by 1897. The National Federation of Day Nurseries was organized in 1898. In 1931 it was estimated that there were approximately 800 institutions that might be termed day nurseries in this country. 3

In 1923 there were 110 day nurseries in England. There was in 1931 some overlapping in the functions of the nursery school and day nurseries but they were not found in the same districts. At that time the day nurseries took children from one month to five years of age. The day nursery provides custodial care only while the nursery school

${ }^{1}$ White House Conference on Child Health and Protection Nursery iducation, Section III Education and Training (Now York: The Century Co.. 1931) p. 7 .

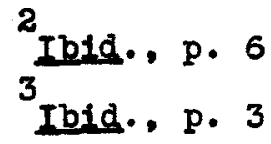


provides both care and training. A day nursery could become a nursery school and obtain grants-in-aid upon completion of requirements lald down by the Education Act of 1918. 1

The definition of day nurseries has changed in the last decade. The White House Conference on Ch11d Health and Protection declared that "the day nurseries provide care for the young chlldren of emplojed mothers, while the nursery school and kindergarten provide educational and training facilities for children of all classes." 2 Contrast this to Miss Imma Lundberg's comments in 1942 on recent trends. "The day care center should Include the recognized features of a good day nursery, incorporating the methods and equipment of a nursery school." Recently day nurseries have come more and more within these requirements by using nursery school methods, and likewise have many nursery schools changed their schedules to offer the all-day program of a day care center. 3

The Department of Social Welfare in the State of Californla derines day care simply as "care given to children who, for various reasons, must be cared for during the daytime by others than their parents. This type or care differs from that of other child-caring institutions or boarding bomes In that no overnight care is given. - Day care, in other words, means a simplified, harmonious environment in which a schedule of daily activities provides the child physical safety, healthy enjoyment, and satisfactory habit training. By this concept, it may be anticipated that children under this

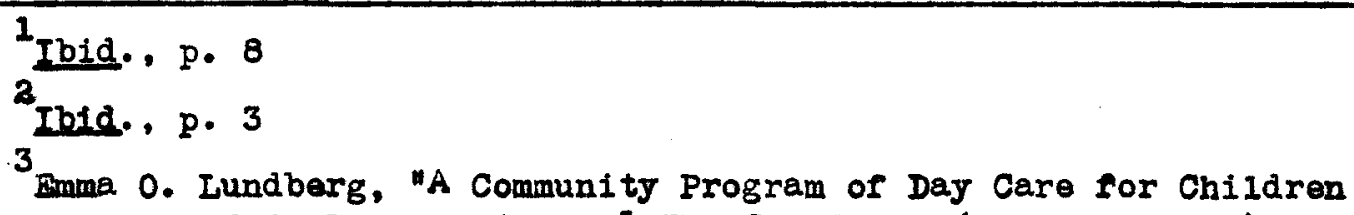
of Mothers Imployed in Defense Areas," The Chlld, VI (January, 1942) p. 157 
type of care will experience the abundant freedom and creative play which are so vital to any young 1ife." 1

Parents should have an active part in any community day care program. They may participate in a number of ways: by serving on plannlng committees; by helping in nelghborhood surveys; by serving on sponsoring boards and by assisting with the actual work of the center. Lany of them may learn a great deal from working with trained teachers and directors. Group meetings consisting of day care leaders and parents offer opportunities for exchange of ideas through such activities as lectures, films on family life and exhiblts as well as a chance for the two groups to become better acquainted. 2 parent education and cooperation are also valueble from the point of view of continuity in the methods that are used in the day care centers and other forms of day care. 3

As far as fees are concerned, according to the existing literature on standards for day care, it is usualiy considered advisable for the parents to pay according to their ability for the care of their children. Although a base rate may be set, many families who need day care will not be able to afford this service. In this event a counselor will be helpful in obtaining information about family resources, earnings and expenses so that a fee may be arrived at, that is fair both from the standpoint of the community and the parent. 4 It has been suggested that in the cases of

IDepartment of Social Welfare, State of California, Standards for Day Care of Children. (October, 1942), p. 1

${ }^{2}$ Connecticut State Department of Education, Child Care Programs, A Report of the Child Care Committee of the State Defense Council (Hartford, Conn: 1942) p. 43

3 Emma 0. Lundberg, "A Community Program of Day Care for Children of Mothers Pmployed in Derense Areas," The Onild, VI (January, 1942) p. 157 4Connecticut State Department of Bducation, Child Care Programs, p. 20 
parents who offer to pay more than the fee asked for their children's care, they be advised to make a contribution in a lump sum to the agency providing the service.

The kind of care that the child will receive should be determined by consideration of his mental and physical condition as weIl as his age. The various types of day care fall into the categories of group care for children of pre-school age, before and after school programs for children of school age, foster day care, and the homemaker service all of which may be accompanied by some type of counseling service. The subcomitter on Standards and Services for Day Care authorized by the Children's Bureau Conference on Day Care of Children of Working Mothers divided group care Into three age groups: those from 2 to 5 inclusive, those from 6 to 11 , and those 12 to 16 jears of age. It was the consensus of opinion of this committee that programs should be planned to suit the individual needs of the children, and that in attaining this goal it is helprul to place children with others their own age.

The day care center is especially sulted to the needs of the preschool child. The program of the 2-5 group is of necessity more elaborate than for the other two groups since children of this age are largely dependent on adults for their welfare. 1 The report on standards recommends that the day care center have a staff selected equipped to give the care necessary for the children. This would include a director with training and experience; additional personnel to the extent of one adult to 10

'Children's Bureau, Standards for Day Care of Children of Working Hothers, Report of the Subcommittee on Standards and Services for Day Care Authorlzed by the Children's Bureau Conference on Day Care of Children of Working Mothers (Washington: Government Printing Office, 1942) p. 1. 
children (with a minimum of two adults for any group, however smali), for "housekeeping and maintenance. . . and for carrying on those parts of the health program that require specially trained personnel, such as physician or nurse. - . for making declsions in regard to admissions, for family counseling, for continuing contacts with parents and for community integration. - . and for handling administrative detail, so thattime that should go to the children should not be usurped by such tasks." I The program should include a schedule of daily activities for adequate service, "provision for health care, provision for active relationship between parents and the program of group care and guidance, and the keeping of records needed to meet administrative requirements and to insure knowledge of Individual needs of children and families." The day cere center 1 tself should conform to local and state regulations in regard to location, safety and sanitation, construction, play space, 11ght and vent1lation, temperature, arrangement of rooms and equipment. 2

The Child Care Committee of the State Defense Council of Connecticut had additional recommendations. They thought it desirable to have a maximum attendance of 15 chlidren to any one center. In the event larger groups had to share the quarters the children should be separated into smaller groups whenever possible. The rewest children should be in the youngest age groups because of health considerations and suscoptibility to fatigue and overstimulation. They advised too, that only a few new children be entered into the group at one time. Each chlid's property

IChildren's Bureau, Standards for Day Care of Children of Working Mothers, Report of the Subcommittee on Btandards and Services for Day Care Authorized by the Children's Bureau Conference on Day Care of Children of Working Mothers (Mashington: Government Printing Office, 1942) p. 1 2 Ibid. , pp. 4-11 
ideally should be marked by something that he can recognize as his own, e. g. a flower, auto, or animal. The children should be free to choose their own activities for the most part. No organized games should be planned before the child is five, and the younger the children the smaller the group should be for stories and poems. I

A typlcal daily schedule for a nursery group comprised of three year olds follows. Time allotments are approximate; smooth dovetailing of activities demands overlapping of each period.

7:30-8:30 Arrival and inspection of children. Drink of water. Until 9:00 Indoor play; music, stories, and conversation in small groups.

9:00-9:30 MId-morning lunch of fruit juice and cod 1iver oil. Toilet. Short rest on cots. 9:30-11:30 Outdoor play

11:00-11:30 Preparation for dinner. Regt on cots. 11:30-12:30 Dinner. Preparation for naps. 12:30-2:30 Naps 2:15-3:00 Getting up. Toilet. Afternoon lunch of fruit juice or milk. 2:45-4:15 outdoor play. 4:15-5:30 Quiet play indoors; music, stories, et cetera. Departure

${ }^{1}$ Connecticut State Department of Education, Child Care Programg, A Report of the Child Care Committee of the State Defense Council (Hartford, Conn: 1942) p. 32-36

Ibid, p. 37 


\section{After-school Care}

Coming more and more into a place of high importance is the service of the after-school program. If a family makes application for day care, the needs of children of school age in the family should be given as careful consideration as those under six. It is usually considered advisable to divide these groups according to age because of differences in interests and development.

After-school groups may be carried on in connection with schools, day nurseries, libraries, community centers, playgrounds, settlement houses and churches. School racilities are especially userul that include a library, lunchroom, gymnasium, auditorium, workshops, sewing rooms, art and music rooms, playgrounds and gardens. In communities where there are a large number of working mothers, the schools may be looked to as a natural resource since much of the necessary equipment is already available to them. 1

The program should be varied and entertaining and planned accordIng to the Individual and group interests of the children. In general, children, 6, 7, and 8 jears old prefer group activities to team games; a fow may make use of simple team play. More of ten than not the children will want to play in small groups and choose thoir own activities. 2 Team games are particulary enjoyed by the 9,10 , and 11 year olds and many of them are quite successful when self-directed. Organized club and bobby groups are popular with this age group also. The existing facilities for

1 Bmma 0. Lundberg, "A Community Program of Day Care for Chilaren of Mothers Imployed in Defense Areas," The Chi1d, VI (January.1942) p.159 2 Connecticut state Department of Education, Child Care Programs, A Report of the Child Care Committee of the State Defense Council (Hartrord, Conn: 1942) p. 40 
education and recreation are given their fullest use in connection with the 12-16 yoar olds. The activities for this group range from highly organized games such as football to Individual sports such as swimming. 1

Rest is important for children of all ages and the school age child is no exception. There should be a time for relation at some time during the day through quiet activities, if not actual rest on cots. The latter should be available, however, for ill, undernourlshed, malnourished. or overstlmulated children as well as those who do not get enough sleep at home. 2

In regard to hours, care should be provided before and after school on week days, all day on Saturdays and if necessary on sundays and during vacations. The winter program may last from about 7:30 A. M. until 6:00 or 7:00 P. M. In the summer, school activities may continue from early morning until early evening, of ten throughout the week. This will be determined by the needs of the children. It may be necessary for one or two meals to be prepared if mothers must work during mealtime. 3

Capable leadership and enthusiastic personnel are required in a program such as this. The director or person in charge should have had both training and experience in group work and knowledge of human behavior. The number of additional personnel will depend on the size and composition of the group. "A sample daily schedule that merely suggests the kind of plan

'Children's Bureau, Standards for Day Care of Children of Working Mothers, Report of the Subcomittee on Standards and Services for Das Care Authorized by the Children's Bureau Conference on Day Care of Children of Working Mothers (Washington: Government Printing office, 1942) p. 13

${ }^{2}$ Connecticut State Department of Education, Child Care Programs, A Report of the Child Care Commlttee of the 8 tate Defense Councll (Eartford, Conn: 1942) p. 38

${ }^{3}$ Children's Bureau, Standards for Day Care of Children of Working Mothers Report of the Bubcommittee on Standards and Services for Day Care Authorized by the Children's Bureau Conference on Day Care of Children of Working Mothers (Washington: Government Printing Office, 1942) p. 12 
that can be used with variety before and af ter school follows:

7:00-8:30 Breakfast. Household duties and indoor play. Outdoor play.

12:00-1:15 Preparation for dinner. Dinner. Outdoor play.

3:30-3:45 Lunch (Iruit juice or Iruit).

3:45-4:15 Outdoor play.

4:15-4:30 Indoor activities - small group or individual play,

club or hobby groups.

5:30-5:45 Preparation for supper.

5:45-7:00 Supper. Quiet activities.

1

Connecticut State Department of Education, Child Care Programs, A Report of the Child Care Committee of the State Defense Council (Hartford, Conn: 1942) p. 42. 
Foster Family Day Care

When chlldren under two must be cared for away from their own homes, foster family day care is usually most desirable, because it is most like the care given the child by its own mother. It is also useful for children of all ages who, because of health or persconality problems will do better with individual care than in a group. It meots the neods of physically handicapped children, of those who have too far to go for an organized group center, and of those who need care at unusual hours. 1

Foster family day care may be defined as oare in a family home other than his own for part of the day. This type of service should be developed by established social agencies in the community; the agency should select the home and supervise the care. Ideally the sociel workers in this type of program should have a fine understanding of family relationships and experience in foster home finding and child-placing. In the selection of the homes the foster mother herself is the most important one factor to be considered. She must be of suitable age and temperament, in good physical condition and willing to cooperate with the parents and the agency. If she can plan for the child's care with the ohild's mother, the chances are better for a successful placement. Proper safeguards for the children's welfare muat be assured by strict adherence to accepted standards. In addition to the requirements mentioned above, the dwelling, equipment, and surroundings should meet the rules established by local or state legislation. The number of children that

${ }^{1}$ Connecticut State Department of Mducation, Ohild Oare Programs. A Report of the Child Care Committee of the State Defense Council (Hartford. Conn: 1942) p. 11 
may be cared for in a foster family home depends upon the home itself and the abilities of the foster mother. Each child should have a physical examination before admission with continuing health supervision. A planned routine helps develop good health habits and should include adequate indoor and outdoor play, rest, and sleep. Sufficient records should be kept by the foster mother to identify the child and enable her to contact the parents in an emergency. 1

There are numerous difficulties involved in this typo of day care service, and as yet it has been developed extensively in only a few communities. It is not likely to meet the needs of large numbers of children, because of the expense that is necessary and the scarcity of suitable foster homes. Most parents, when given a cholce between day nursery care and foster day care will choose the former partly because of the fact that it is better known to them as a means of caring for their children. Paychologically, it may be hard for them to admit that other parents may be more successful in raising their children, and they are afraid that their children w111 become too attached to the foster day parents. 2 Nonetheless, foster day care may be able to $f 111$ many of the gaps in other day care programs and will probably become most useful as a device for dealing with certain children.

\section{Homemaker Service}

Supervised homemaker service provides care for children in their own homes, when the mother is absent from the home or when she is in the home, but

1

Children's Bureau, standards for Day Care of Children of Vorking Mothers, Roport of the Subcommittee on Standards and Services for Day Eare Authorlzed by the Children's Bureau Conference on Day Care of Children of Working Mothers (Washington: Government Printing Office, 1942) p. 20 ${ }^{2}$ Katherine Dell. Phelps, Foster Day Care, (Montclair, N. J, Council of Social Agencies, 1942) pp.1-5 
cannot properly care for her chlldren because of illness or some other reasen. The service is provided by famliy agencles and child agencies and until the early part of 1943 was provided by the HPA. It is userul in emergencies, or in special instances when the mother has to go to work, and there is no one at home to care for the child who is sick and unable to go to a day care center, foster home or school. I The long range values of the service are great. Orten in the low-income ramilies santation standards are raised, the physical care or the children is improved and there may be a positive change In the family relationships as a result of the meals being prepared on time and the house being clean. 2

The administrative service should always be carried on by an established case-work agency that will give service to the family, supervision to the homemaker and a training program for her development. Training is usually concurrent with the job. If this type of service is to be effective, the family should be given counseling service, including information about other faclities for child care. There should also be recognition of the homemaker as a semi-professional person and personnel practices should be attractive enough to invite competent women to enter the the field. ${ }^{3}$ It is admlttediy the most expensive form of day care, but there are situations in which it is advisable. It has been suggested as a means of meeting the need of professional and business women who can afford adequate service, but as yet this has not been explored to anj great extent.

${ }^{1}$ Children's Bureau, Standards for Day Care of Children of Working Mothers, Report of the Subcomittee on Standards and Services for Day Care Authorized by the Children's Bureau Conference on Day Care of Children of Working Mothers (Washington: Government Printing office, 1942) p. 15 2 Proceedings of the Conference on Day Care of Children of Working Mothers Beld July, 1931 and August, 1941 (Washington: Government Printing Office, 1942) p. 68

${ }^{3}$ Children's Bureau, Standards for Day Care of Children of Working Mothers. (Washington: Government Printing Orf1ce, 1942) p. 16 


\section{Counseling Service}

A service that should be available in every community in which there is a day care program is that of counseling. Mothers who are intending to go to work, mothers who are already working and mothers who do not work, but send their chlidren to a center for part of the day may need this service. Mothers intending to go to work may have questions about their employment problems, problems of: child care and home maintenance, family feeding, health and safety, housing, recreation, family relationships. 1 Family counseling service should be continuousiy accessible to parents who need help in thinking through problems that may arise as a result of the child's being taken from the home. They may not be aware of the existing community resources in the fielda of education, recreation and other areas. 2 Counseling should not be offered indiscriminately, however, and it is advisable not to have the service unless a trained care-worker is aval1able. Occasionally adequate individuals may be found in other fields, but care should be used in recruiting them. The community or section of the community interested in the service will necessarily decide the place that w111 be used the most by parents when they desire to talk over their problems related to child care. Some will choose the employment service, some the day center itself and some the family or children's agency. In any event, the the type of care offered, the economic status of the parents using the center and the geographical location of the case-worker employed to give the servioe

1. S. Office or Education, "Information and Counseling Services in the Extended School Program," Education for Victory (Washington: DEC. 1942) Vol. 1, No. 19, p. 1

${ }^{2}$ Connecticut state Department of Education, Child Care Programs, p. 21 
will determine to some degree the location.

There are many and differing theories as to the value of nursery education and the dangers of mothers going to work. Some authorities believe that childbood is the time when human beings gain their security and that nursery education should be universal. One source points out that physical growth is comparatively inevitable, but that "social growth, learning to live with other individuals,. . . Is the province of education." Through nursery school education be may find himself between absolute conformity and absolute freedom thus developing into an individual inhis own right but at the same time having the ability to live within the limits of convention. In order that their children might grow up to be well-adjusted adults, however, is not the most common reason that parents have for sending them to day centers, or seek some other form of day care. Most of the children who occupy day centers and nursery schools are children of parents whose mothers must work from economic necessity, or who seek employment for patrlotic reasons or because housework is boring to them, or who realize that a small apartment does not offer adequate play space to the young child. 2

In contrast to the adage that "woman's place is in the home," Foster and Mattson continue that many mothers we11-trained for their careers, dis11ke giving them up aftermarriage and have their entire time ocoupied by housekeeping. "parents who look to the nursery school are not shirking their

1W. E. Blatz, D. M1111champ, and M. Fletcher, Mursery Education (New York: William Morrow andOo., 1936) pp.8-18.

Zwhite House Conference on Child and Protection Nursery Education Section III Education and Training (New York: The Century Co., 1931) pp.3-4. 
obligations to their children. On the other hand, they may be insuring their children of pre-school age early training in soclal adjustment, and opportunity to develop habits of self-reliance in eating, sleeping, playing, and in attending to personal needs. ..." 1

In Europe, the day centers employing nursery school methods or not are recognized social agencies, but they have been looked on with disparagement in this country to some extent and have recelved little support unt1l recentiy from public funds. Part of this may be due to fear that women would take many job opportunities that rightfully belonged to the men if provision were made for the children; it was also realized that the European system of placing babies under two in centers or homes was not a sound policy. In an attempt to allow many high school students to finish their training instead of keeping the children of working mothers, Los Angeles was supporting 32 out of its 38 day nurseries with pub11c funds in 1931. 2

It would seem that the day care of children of pre-school and school age would fall within the function of the educational system. Training a one kind or another should be apparent in all forms of day care. At this t1me, however, the schools are not prepared to take over this service and until they are, it will probably remain in the hands of interested agenoies and individuals.

The first day nurseries, begun in Europe, were a far cry from modern day center with its trained personnel, well-equipped plant, comparatively smali number of children admitted and its program that provides training for

IJ.C.Foster and M.L.Mattson, Nursery School Procedure (New York: D. Appleton and Co., 1929) Introduction, p. IX. 2

White House Conference on Child and Frotection Nursery Education Section III Hducation and Training (New York: The Centry Co. 1931) pp.6-7 
good social adjustment. Mothers who had to support their families often were forced to leave their children in dark, over-crowded institutions with the result that group care fell 1nto disrepute. For decades it was used only by those who could afford anj other resource for their children.

With the establishment of nursery schools, attention was centered on child training, although many of them encouraged spontaneity and used methods approved of today, there were others especially the English schools, in which the children gained little more than training in social conformity. In most of the schools only children in the high income groups were enrolled.

In the United States numerous day nurseries were established primarily For children in low income groups after the turn of the last centruy. It was not until during and after the first World War that the nursery school movement became popular. Many schools were begun in connection with research Institutions interested in child development, or as cooperative schools financed by a group of parents.

In recent years the nursery schools and day nurseries have begun to slowly converge in theory and practice and although differences may still be found in the two kinds of care, each has borrowed and made use of much thet the other had to offer. An Ideal day center is a combination of a nursery school and day nursery and serves children of every income level.

Although day care is usually associated with group care for the pre-school child the term is more inclusive. After school service for the school age child is nother phase of day care which offers recreation programs for youngsters after, and occasionally before, school if the mother must work on an early shift. Another type of day care is foster famliy care which refers to a progam for not more than six or eight children in a home 
that is chosen by a recognized children's agency. Foster family care is advised for the child under two, the child who cannot fit into a group because of some physical, mental or emotional handicap. For chlldren who do not live near a day center, foster family care is valuable.

The homemaker's service is used when a mother is ill or for some reason cannot care for her children for a limited period of time. The homemaker goes into the home; ber duties are set forth and supervised by a social work agency, which has had experisnce in working with homemakers, possibly in a teaching capacity. This 1 s the most expensive form of day care; It has implications, bowever, for the family whose income is sufficient to use It.

Counseling service for mothers who are contemplating day care for their children, as well as mothers whose children are already being cared for outside the home, is coming to be recognized as a necessity for an adequate day care program. Many centers have found it satisfactory to borrow caseworkers from local agencies for this purpose.

Thus is illustrated the trend that is evident in the history of day care to become more specialized, to attempt to meet the needs of the Individual chlld so that he may be given every opportunity for personality growth. 
CHAPTER II

DAY CARN AND THE PRESENT EMERGENCY 


\section{Chapter II}

Women in Industry

At the core of the problem of day care for children of working mothers is the whole question of manpower and the adequacy of the supply. If It is assumed that the two main classes of women interested in day care are mothers who need to work for economic reasons and mothers who work because they feel it is their patriotic duty to seek employment, it seems logical to explore the actual need for women in industry.

Militions of men in the armed forces and still greater numbers in war production made it inevitable that women would be called upon to increase the depleted labor supply, and to take jobs they were not asked to take in the last war. Since the United States entered the war, women were considered to take important roles in the flelds of radio operation, tool making, radio repalr work, welding, sheet metal work and varlous jobs formerly thought to be exclusive for engineers and carpenters.

Some relaxation of discrimination against women by employers was noted; in many companles the degree of skill required of workers was the decisive factor in determining the policy of an industry. Some employers, and the office of Education as well as other national agencies offered courses for skilled labor. In Californta the occupational Analysis Section of the United States Hmployment Service analyzed the work done by 1,859 women in 21 war industries and 937 non-war industries and concluded that if some of the more complicated jobs were broken up into two or three parts, there would be few jobs that women could not hold. 1

1 M. A. Joiner and C. Weiner, "Mmployment or Women in War Production," Social Security Bulletin V, No. 7 (July, 1942) pp. 10-12 
In 1940 employment of wonen increased and in the last quarter of 1941 there was a $\mathrm{rlse}$ of $63 \%$ in their placements in industry. ${ }^{1}$ In September, 1942 the Women's Bureau, Department of Labor, War Manpower Commission published the following estimates:

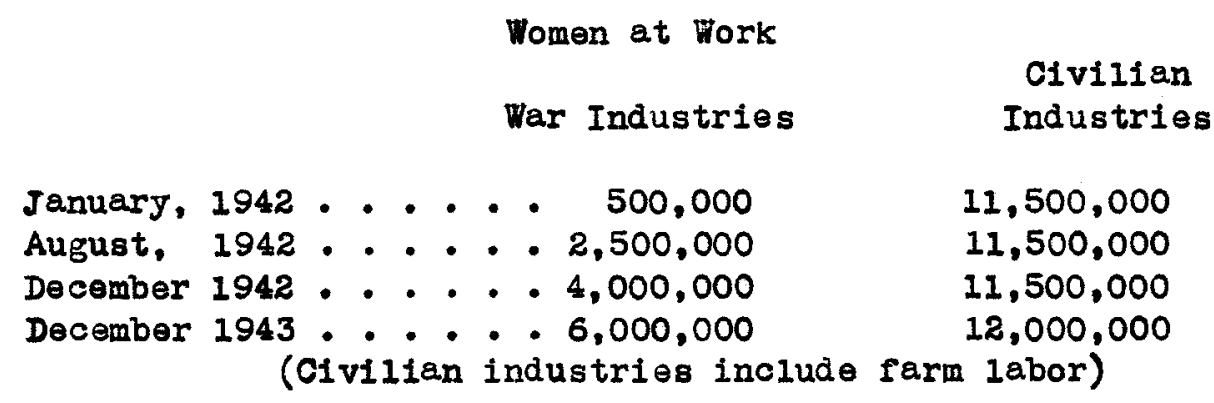

According to their estimates, "to 1111 the 1943 needs, one woman out of every six over 18 years of age must enlist her services either in essential war material production or in those other branches of civilian employment. - . necessary to maintaining the free life that Americans cherish." 2

What are the ages of these women? In March, 1940 working women as a group had a medion age of thirty-one. 3 Another source states that, "the chier reserve labor supply 1 s among women 18 to 44 jears old." 4 By October, 1942 all centers of war industries knew that many women with children were already being absorbed into the labor pool. In Tacoma, Washington, there were 4,000 children, aged six to fourteen, with both parents employed (this did not include pre-school children); in Detrolt,

I Ibid., p. 10

"Free Labor Will Win, 'Say Women Workers," Courler-Journal, October 18, 1942 .

3 M.A.Jolner and C.Weiner, "Imployment of Women in War Production," Soclal Security Bulletin V, No. 7 (July, 1942) p.7

${ }^{4}$ G.T.Allen, Maxine Davis, Werner Olivier, "gight-Hour Orphans," Saturday Evening Post. (Ootober 10, 1942) p. 20 
It was estimated that in the near future mothers of 80,000 children would be employed; a St. Louls study showed 4,068 mothers already working; in Connecticut war workers needed care for 25,000 children. ${ }^{1}$ According to the employment service's statement in September, 1942, "women are ahead of the employers in recognizing the fact that demand for competent women factory workers is increasing by leaps and bounds. . ." 2

It was thought there would be an acute need for women in dustry by the spring of 1943, but this did not prove to be the case. In November, 1942, there were 5,200 women working in Loulsvilie and its environs 3 and the number increased in the following $81 x$ months but not to the degree that was anticipated. On the contrary, many men working in the defense plants in Charlestown, Indiana, just across the Ohio River from Loulsville, became unemployed. 4

In an interview with a member of the $100 a 1$ organized group of personnel directors, it was revealed that many local employers hesitate to take women into their employ because of the inadequacy of the $100 a 1$ day , care facilities and also because there still exists a great deal of prejudice toward employing women until it is absolutely necessary to "scrape the barrel." There seems to be some aversion to group care for children on the part of this same group, and caution in their recommendation for establishment for day centers that might not really be neoded. 5

IMary C. Bingham, "Home Front 'War Orphans' Mustn't be Neglected," Courler-Journal, Ootober 15, 1942

2M.A.Joiner and C.Weiner, "Bmployment of Women in War Production," Soclal security Bulletin V, No. 7 (July, 1942) p. 14

${ }^{3}$ Statement made by Mr. More Helm, United States Employment Service, Louisvilfe, Ky

Statement made by Mr. Joseph Ware, representative of the office of Defense Health and Welfare Services.

${ }^{5}$ Statement by Mr. John Eouchins, Epeed soientific School, University of Louisville. 
In England the use of women in Industry has advanced much further than in this country. Barly in 1942 there was compulsory registration of women between the ages of 18 and 45 for employment. Tives of servicemen and women with obildren under fourteen were classed as "immobile workers" and could not be moved about, but the remainder of the registrants could be sent to any locality in whlch they were needed. ${ }^{1}$ From January, 1940 to June, 1941, unemployment decreased from 440,000 to $153,000{ }^{2}$ According to the Ministry of Information, 332,000 women were with the fighting forces; 105,000 on the railways; 20,000 worked on subways and buses; 125,000 were clerks and carriers; 6,700,000 were full-time workers and 250,000 were part-time workers. 3

Part-time work was advocated as one of the solutions to the labor problem in Ingland in the fall of 1942. It was noted that in many cases both the mother and children were suffering from the mother's working full-time, while those who had tried part-time work were pleased. It was suggested that the Ministry of Labor survey all occupations and list those that could be worked on a part-time basis. It might be desirable to separate the Bureau for Part-Pime workers from the Fmployment Bxohange but keep them under the same management.

Part-time work oan take various forms:

1. Morning and afternoon shifts (one in the morning and one in the afternoon).

\section{Three full days a week;}

1 Newsweek, XX, No. 26, (December 28, 1942), p. 38

ZM.A.Joiner and C.Weiner, "Employment of Women in War Production," Soclel Security Bulletin V, No. (July, 1942) p. 9

3 Newaweek, XX, No. 26 (December 28, 1942), p.38 
3. A short shift, such as 9:00 A.M. to 4:00 P.M.

Two women with children can arrange for one of the women to look after the children of both while the other woman is working. For mothers who live near their work the first plan is most convenient, but for those who have to pay transportation the second plan is most sultable.

Lady simon continued that "women are eager to volunteer for parttime work, but the diffioulty lies with the employers who are hesitant to make the necessary readjustments. Those who have made the experiment have found they get better production and there is less absenteeism. Part-time employment involves less danger to the children's and mother's health. What is of equal importance is that there is a labor supply avallable that can't otherwise be tapped." 1

Negative criticism of mothers working is heard on all sides. Before one can say that any motber who has certaln skill is needed in the labor market, one must constder all the aspects. If the mother goes to work because of economic pressure, Henrietta Gordon wrote, "we begin to wonder whether a mother should leave her home and children to become a breadwinner. The public relief program should be extended--Aid to Dependent Children and Eome Relier should be sufficient to enable mothers who. . . should, to remain at home and care for their familles. 2

Bimilarly, Marshall Fleld, chairman of the National Citizens' Committee, of the White Eouse Conference on Children in a Democracy, urged In November, 1942 that we think first before encouraging mothers to enter

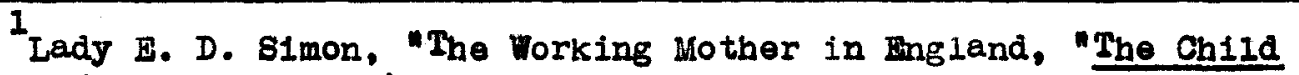
VII, No. 5 (November, 1942) pp. 62-64

2 Henriette L. Gordon, "The Impact of National Defense on Child Welfare," The Family, XXIII, No. 1 (March, 1942) pp.3
} 
industry. "I find myself extremely impatient with those who write articles under such captions as 'Help Mothers Win the War!'. . . For years we have been working for social legislation that would enable mothers to care for their own children. . ."

He continues that "women's work is never done" and that no mother can properly care for her household and children after eight hours' work in a factory. In addition there is the danger to the child's physical and emotional condition that results in his separation from his home and regular routine. 1

The War Hanpower Commission on August 15, 1942, Issued a directive relating to the employment of mothers with yaung children. In it was recognized the necessity of a certain number of women in industry, but at the same time it was realized thet "to the maximum extent, normal family life (should) be preserved and maintained." Certain fundamental policies were declared to achieve that end:

"I. The first responsibility of women with young children, in war as in peace is to give suitable care in their own homes to their children.

II. In order that established fam1ly life may not be unnecessarily disrupted, special efforts to secure the employment in industry of women with young children should be deferred unt1l full use has been made of all other sources of labor supply.

III. Barriers against the employment of women with young children should not be set up by employers. The decision as to gainful employment should in all cases be an individual decision made by the woman herself in the light of the particular conditions prevaling in her home. 
IV. Whenever it is found that women with young children are gainfully employed in essential activities, or that the labor requirements of essential activities have not been met after the exhaustion of all other sources of labor supply and that to meet such requirements, women with young children must be recruited, it is essential that:

(a) Such women be employed at such hours and on such shifts as will cause the least disruption in their famliy life; and

(b) If any such women are unable to arrange for the satisfactory care of their children at home during their working hours, adequate facilities be provided for the day-care of their children during working hours. Buch facilities should be developed as community profects and not under the auspices of individual employers or employer groups." 1

Thus is illustrated the interest on the Federal level that reflects the country-wide concern over a problem in which the statistios vary from day to day. There is one point of agreement, however, namely that women with young children should not work until every other labor resource has been exhausted.

The Experience in Fingland

Before scrutinfizing our own efforts to solve the day care problem, the British may well be reviewed. In Ingland the program of day care for children of working mothers was far behind other developments in mobilization. The potential demand for care was underestimated; long-term plannIng as related to womenpower was absent from 1939; the establishment of day care centers was left too largely to the local authorities. Long after the

\footnotetext{
1. "Policy on Employment in Industry of Women with Young Children," Directive issued by the War uanpower Commlsaion, \#3868, (August 15, 1942) p. 1 .
} 
need has assumed huge proportions, in the summer in 1942, the program expanded to the extent of beginning to provide adequately for the care of the children. 1

The nurseries are financed mainly by the Government which reimburses the Local Authority for all approved expenditures. There are two main kinds of day nurseries: whole-time and part-time. The former are open from 7:00 A. M. to 7:00 P. M. and take children from two to five years of age. The usuel foe is twenty cents per day. Part-time nurseries are open normally during school hours, from 9:00 A.M. to 4:00 P.M. They take children between two andfive only. Hours may be extended if the mothers want their children to have breakfast and tea as well as the midday meal at school. Five cents for each mee.l is charged if the mother is able to pay. The Mothers' contributions usually cover about one-fifth of the total cost. 2

Another resource for working mothers is that of the "minders," who are somewhat similar to the well-known "nannies," who are listed by each Local Authorlty and used especially in the factory towns. The minders are supposedy dependable women capable of caring for children. The methers usualiy pay a nominal fee and the Government adds the remainder of the total cost. Hore and more responsibility has been placed on the mothers in relations to the administrative phase of the progrem as the duties of the Local Authority have progressively increased.

In addition to this type of care and the nurseries, there were nursery units set up in large and medium-sized residences in reception areas. A "host" is asked to take four to twelve children depending on the

${ }^{1}$ People in Production, Mass Observation Roport for Advertising Service Gulld (Iondon: John Murray Co., 1942) p. 187

2Minifred C. Cul11s, "Nurseries Free Working Hothers," Bulletins Erom Britain, No. 79 (New York City, British Library or Information, Marob, 1942) P. 11 
size of the house. The Minlstry of Health and the local Child Welfare Authority supply equipment and pay the belpers. Other organizations are colonies sponsored by Foster Parents' Plan for Mar Children, which are largely supported by contributions from the United States. They cater to young maladjusted, nervous children. The Hampstead Nurseries are an example of this type of care.

Before the war the Government arranged for all mothers with children under five to be evacuated with them. They left but most of them drifted home in a short time. Better planned and more successful are the residential schools, which are houses in the country into which evacuees in 48 of the 166 nurseries under the soclety of Day Nurseries moved. The routine of the day schools was carried on and practically none of the children were recalled by the parents. 1

By the end of 1942 the Anglish program was by no means perfect. While more women were needed for industry, seven out of ten women were said to have been willing to work if their children were cared for properly. It was thought there was potential goodwill toward the nurseries and in reality they were preferred to neighbors, but many mothers complained that they were too far from home, thet many were dirty and disease-spreading and that the nursery hours did not colncide with working hours. Nearly one-tenth of the mothers had their name on the waiting lists; the supply still fell short of the demand because of shortages in space, equipment, and stafr.

The British Mass Observation Report states that one of the drawbacks (In the situation of working women and nurserles) is "the high standard of domestic pride the more intelligent and energetic woman has." Many of them think, as a result of the Government propeganda and advertising, that

\footnotetext{
"The Under-Fives" Bulleting from Britain, No. 84 (April 8, 1942). pp. $7-10$
} 
'keeping up morale' is enough for them to do toward the war effort. Along this same line is the belief that men should not expect the standards of peace-time in housekeeping; as the difficulties the average mother has in shopping for and feeding her family are well-known. 1

In November, $1942 \mathrm{Mrs}$. Roosevelt, in her visit to Ingland, discovered Industry and the Government attempting to partially solve the problem of feeding the families of women who worked. There were approximately 17,000 factory canteens and 1,721 Government restaurants for factory families which reduce the housewives' domestic duties. At the Food Ministry she was told "any employer who doesn't look out for feeding his workers belongs to a bygone age." 2

\section{Federal Measures Concerning Day Care}

One of the first evidences in this country of interest in day care on the federal level was the Conference on Day Care of Children of Working Mothers held in Washington, D. C. July 31 and August 1, 1941. Represented at the conference were soclal workers, teachers, government orficials and Industrial leaders, which were thought to be the main groups in which day care was being discussed at that time. 3

A number of principles to safeguard children came out in the two days' activity. It was agreed that mothers should be persuaded to stay at home, if possible; employers and unfons would be asked to keep mothers on the day shift; and consultation service should be offered by the state Department of Public Welfare and the State Department of Education. Day

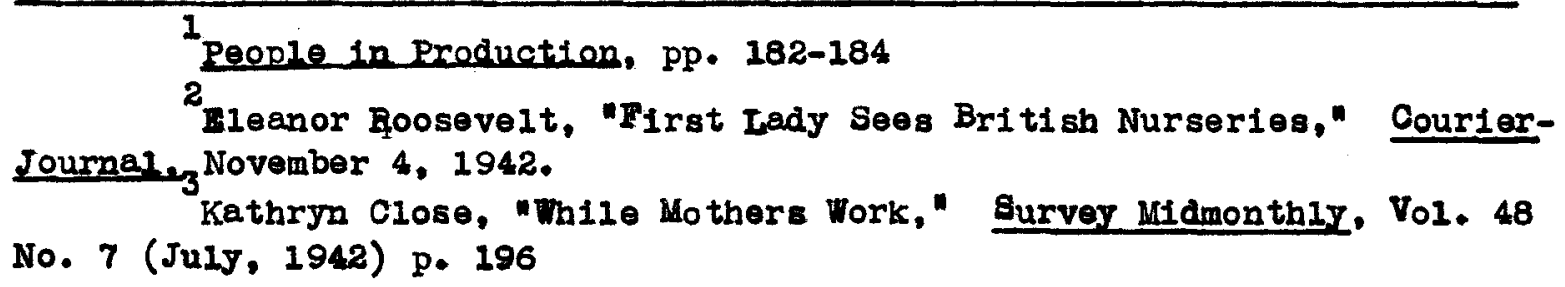


care was consldered in relation to the all-over pattern of community organization and it was thought that programs should be based on a definfte analysis of the need. These day care programs should include a central counseling service, day care centers, homemaker's service, foster family day care and extended programs in the existing nursery schools. 1

Two Federal programs through which communities might receive funds for providing funds for children's care consisted of the program financed by the Lanham Act which gave assistance for War Public Works and War Public Services and the Works Project Administration Program. The Community Facilities Act was passed by Congress on May 28th, 1941. It provided for the establishment of new day care centers and extending the services of established ones but under no circumstances were funds provided for food. Communities were required to have war-caused needs for group services to ch1ldren 2 and until December, 1942, it was necessary to prove that these needs could not be met except through Federal assistance. At that time the requirement of "deficit financing" was removed.

Additional polleles were as follows:

"Applications must be made by public agencies with legal authority to supervise or operate such activities in the area concerned and/or private non-profit organizations which can show legal authority to supervise or operate the ectivities requested. When no agency has such authority the State authority having power to allocate responsibility for emergency work may designate an agency to take the responsibility and make applications.

1

Ibld. p. 197

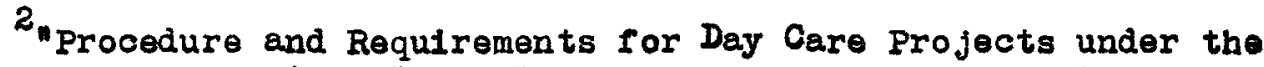
Community Facilities Act, "Blue Bulletin, F.W.A.A., series B, No. 12, (May 15, 1942) p. 1 
Applications must show that the activity planned is part of an overall community plan, and must have the approval of a community committee on children's services if such a group exists.

Fees may be charged on a sllding scale and the famliy's statement or ability to pay shall be accepted without the necessity of a casework investigation.

Teachers and other workers seoured through Lanham funds may be used to supplement nursery schools employing WPA labor and vice versa." 1 The funds were made available to the Children's Bureau and office of Education; in order to secure the funds it was necessery to obtain the approval of the office of ducation for centers conducted in schools and for those conducted elsewhere, that of the Children's Bureau. Regardlese of the department chosen, the Federal Works Agency had jurisdiction over the progran. 2

The method of obtaining Federal funds through the Lanham Act have varied since their allocation; there was a great deal of confusion as to the best avenue of approach. According to a representative of the ODHWS the steps to be taken in March 1943 were as follows:

1. The public or private agency with legal status or individual making the application is assisted by the WPA, the State Department of Hducation and Federal representative from the ODEWS, the Children's Bureau and the United States office of Education:

2. The state representatives of the FinA or the WPA inspect the application and write it up, to be signed again by the sponsoring agency:

\footnotetext{
I"Children's Services, "Federal Works Agency publication, (Washington: September, 1942) p. 1-2

F.M.A.A. Blue Bulletin, p. 1
} 
3. It is then "processed" by the State WPA and the regional WPA and copies are distributed to various state and federal people in the welfare and/or educational fields;

4. After 1t is approved by the FWA in Washington, it is recommended for presidential approval after which it goes back to the local sponsor for acceptance. 1

The second Federal program to become attuned to war-time needs was the Child Protection Program of the Works Projects Administration, also under the Federal Works Agency's jurisdiction. At the time of Pearl Harbor, WPA already had some 1,500 nursery schools and about 1,200 pre-school play groups. 2 After this country's entrance into the war, the program expanded. The 1943 Imergency Reller Appropriation Act provided that "not less than $\$ 6,000,000$ to be used exclusively for the operation of day nurserles and nursery schools for children of employed mothers." 3

There were three types of nursery schools under this program. The "Type A" nursery schools and the pre-school play groups continued much as they operated before the outbreak of war. Children from two to four inclusive could attend; five-year olds could be enrolled only when it was certain that the earlier ages were cared for, when facilities were not available through school regulations and too, the five-year olds could not exceed ten per cent of the total enrollment. This type of care was primarily for low-income groups; parents on federal or state relief or work relief and similar low-income families.

The "Type B" defense nursery schools were located only in officially designated defense areas and were primarily for children or employed mothers.

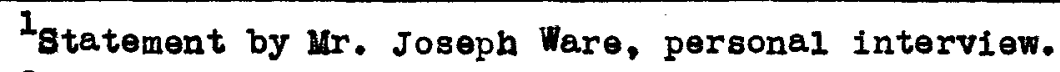

2"Broadcast on Nar Nurseries and Day Care of Children..." Federal Works Agency publication (Washington, November 4, 1942) p. 2

3 "Children's Services," p. 2 
The ages were two to four inclusive, but five-year olds were included only if no provision for them was made by the public school system for the twelve month period prior to the concentration of population giving rise to the need for defense nursery schools and if no provision could be made by the public school system. Five-year-olds could be enrolled during the time pending prom vision of the sohool facilities, but they could not exceed fifty per cent of the total enrollment. Children who were eligible for enroliment in the "Type A" nursery school could attend the latter type but they could not exceed twenty-five per cent of the total enroliment. Cesh contributions were on a sliding scale determined by the sponsor, WPA, and a recognized social service agency. It was a policy that WPA employees should not collect or handle cash contributions. 1

The "Type C" nursery school was for children of men and women in the armed forces and children of industrial workers. They could be established only in officially deslgnated defense areas, for 2,3 and 4 year old children. The provisions for children five years of age are the same as for those under "Type B."

In addition to these group services for children, the Commissioner's letter of August 28, 1942 mentioned the related parent and family 1ife education service. Included under this would be "Classes for families, informal contacts with parents, visits to the home, provisions for obseryation by the parents of group activities of the children and participation in these activities when possible." 2

\footnotetext{
1 Child Protection Program, " TPA letter June 30, 1942 2Service Letter No. 6, April 21, 1942 and Commissioner's Letter No. 68, August 28, 1942, pp. 1-3
} 
Another new service that was permitted was the Day Nursery Service for five to ten year old children, supplementary to the program of the public school system. Activities were extended to reach the chlldren during the hours the mother worked, at noon and during vacations and bolidays. ${ }^{1}$

In regard to personnel, it was possible that when sufficient personnel was not existent from the certified rolls to adequately staff nursery schools, to request exemptions for non-relier and non-security personnel. Standard hours of employment would be maintained. Volunteer ald, including a number of students from high school and college were used in the program, having been secured through the local agencies.

All phases of the whole progrem worked under the sponsorship of the public education authorities. Many of the nursery schools had advisory committees which were represented on community planning committees or they may have been in operation for some years and had become the community committee. 2

In JuIy, 1942, the War Manpower Commission discussed the problem or day care as it related to the labor supply and a section especially devoted to day care was established in the office of Defense Health and Welfare Services as a result. The Commission approved the move to issue a direotive "to develop, integrate and coordinate Federal programs for the day care of children of working mothers. " 3 The directive is as follows:

"I. The office of Defense Health and Welfare Services, in consultation with such departments and agencies of the Federal Government as

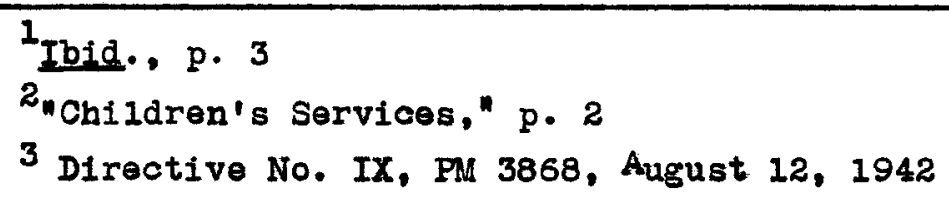


it may deem appropriate, shall:

(a) Promote and coordinate the development of necessary programs for the day-care of children of mothers employed in essential activities;

(b) Determine, elther directly or through such Federal departments and agencies as it may designate, areas in which such programs of day-care should be promoted, and the respective responsibilities of the Federal departments and agencies concerned in the development of such programs; and

(o) Take such action as may be necessary or appropriate to assure the effectuation of all such programs.

II. The Unfted States Imployment Service shall prepare, keep current and make available to the office of Defense Health and Melfare Services, date reporting 1 ts best estimates with respect to the number of working mothers with young children, and the anticlpated requirements of essential activities for the employment of such mothers, by periods and areas.

III. The Works Projeots Administration in the Federal Works Agency, the Children's Bureau in the Department of Labor, the Office of Education in the Federal Security Agency, the Parm Security Administration in the Department of Agriculture, the Federal Public Housing Authority in the National Housing Agency and every other Federal Department or agency carrying on ch11d day-care programs or programs related thereto shall make available to the Orfice of Defense Health and Welfare Services reports with respect to such day-care programs or programs related thereto, carried on by such department or agency, and shall take such action as may be necessary or approprate to insure the integration and coordination, through the office of Defense Health and Welfare Services, of all Federal programs for the day-care of chilaren of working mothers and otherwise to carry out the purposes of this 
directive." In general it might be sald that the Day Care Section might serve as a clearing house and central source of information as well as a planning and integrating body. I

To further the objectives in the directive, the president allocated $\$ 400,000$ to the Office of Defense Health and Welfare Services on August 28 , 1942. In making the funds available to the U.S. Office of Bducation and to the Children's Bureau, the President said:

"The need for child care grors out of an increasingly acute problem of labor supply. I believe that much can be accomplished locally toward meeting such needs as may arise, provided stimulation and coordination of effort are achieved."

The president further stated that the funds were to be used "to provide advisory and supervisory services." 2

It was decided that grants would be made to the States only after the states had submitted plans showing that no other state or local funds were available for carrying out the program.

When the Children's Bureau Advisory Comittee on Day Care met in Washington in october, 1942 the following motion was adopted by the Committee:

- Thet the Committee go on record as favoring federal aid for providing care of children of working mothers distributed in the form of grants to State Welfare agencies through the Children's Bureau and to State Education departments through the office of Education such aid to be adminiatered in such a way that the states will act in turn with local communities on the basis of sound planning, coordinated procedure and flexibility

1"The Day-Care Program of the Federal Government," Office of Defense Health and Welfare Services, July 27, 1942, p. 4

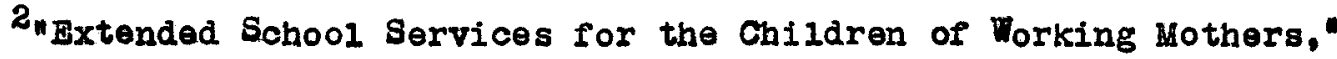
U.S.Office of Education, Ootober 21, 1942 p. 1 
of program with the utmost possible speed and cutting of red tape." 1 Federal representatives at a meeting of the National Councll of Local Publ10 Welfare Administrators frankly acknowledged the lack of clarity in the actual administrative relationships on the federal level as they applied to Lanham Act funds in the first weeks of 1943. Out of the entire group of seventy odd administrators representing the same number of communities throughout the country, none had actualiy received Lanham Act funds, although several had particlpated in applications on behalf of their respective communities. The possibilities of the termination of the WPA program was a further conflicting issue. 2

\section{Dey Care Activities in Other Cities}

Cities throughout the United States were conscious in varying degrees of the problem of day care in the latter part of 1941 and 1942. Some had experienced extreme emergency situations when war demands had increased the number of working women by leaps and bounds in their 10calities; others had placed more emphasis on prevention and had time to make more adequate and complete provisions for the children of working mothers. A somewhat scattered plcture of the plans that were made and others that were carried out was obtained from fifteen cities by correspondence with individuals and agencies in those communities. A brier summary of the work done by five of these oitles follows.

By October, 1942, Seattle, Washington, had twelve day nursery units with more than 400 children enrolled. Three had existed for a number of jears sponsored by the Community Funds. These had changed their hours to a longer day - 7:00 A.M. to 7:00 P.M. The Seattle Public schools had

\footnotetext{
I"Washington Conference," Day Nursery, December,1942 p. 6

2 statement in letter from Ralph 1 . Spear, January 12, 1943
} 
nine units supplied with WPA personnel. Federal funds were requested but pending their receipt the schools advanced the equipment and maintenance costs. These centers were underwritten by the Commonwealth Funds because of rulings on public school expenditures for children under five years of age.

Two supervised recreation programs were offered by the school five days a week from the time school was out t111 6:00 P.M. The fee was 50f per day and the parents gave legal control of their children to the schools during this time.

The Seattle Day Care Committee was organized by the Councll of Social Agencies in March, 1942. It was composed of both profeseional and lay people. Its first project was an information and counseling service for mothers who were working or intending to go to work. The staff was provided by the Family Society with a caseworker located in the War Commission Offices. The Family Society also temporarily loaned a staff member to assist with the work of the Day Care Committee, two other caseworkers were loaned to the Department of Public Welfare to help develop the foster day care program, and another worker was placed in the employment office of one of the largest war industries for a two weeks' period to obtain further indication of need. Publicity of the program was given in all the daily newspapers, labor papers and community papers as well as over the radio. The University of Washington of fered complete training in the nursery school Field.

A survey showed need for nursery schools, after-sohool supervised activities and a foster famliy day care program for which about fifty homes were approved. It wes estimated that in Seattle and King County at least 10,000 children were in need of day care. On this basis federal funds were requested for forty nursery schools and sixty supervised after-school activity 
programs. 1,431 children were actually registered in october as neoding care. 1

For months before the United States entered the war, a committee in Cleveland, Ohlo studied the needs and facilities for increased day care. After December 7, this committee 1mmediately became a joint committee of the Welfare Federation and the office of Civilian Defense. A counseling service was instituted and in six months there were almost 1,000 requests for day care. In response to an appeal in the local newspaper, more than 300 women offered to take one or more children by the day with the understanding that their homes would be licensed and investigated by the state. The real answer to the total problem seemed to lie in subsidizing by grants from war chests, foundations and government funds the desired new and expanded day care facilities. 2

In Jenuary, 1943, there were four centers in Minneapolis, Minn. for children of pre-school age. At that time the Central Planning and Research Department of the Minneapolis Council of Social Agencies issued a "Brier Statement on Child Care Centers, After-School Programs and Foster Day Care Program." The Board of Education had not yet approved the after-school program, but it was through that application would be made for Lambam Act funds for this type of service. A plan for foster day care was proposed in October, 1942. Most of the administration of this program was delegated to representatives of the children's agencies. 3

"A Community Plans for Day Care," The Dey Nursery, December, 1942 pp. $1,12,13,14,15$.

2Mrs. Laurence Hamill, "Day Care in Cleveland," The Day Nursery Deoember, 1942, pp. 7-8

3 "Brief Statement on Child Care Centers, After-School Programs and Foster Day Care Program," (Minneapolis Council of Social Agencies, January 1943), p. 4 
Two cities in Conneoticut, Hartford and New Haven, beoame quite active on the problem of day care in 1941. It was in the summer of that year that the New Haven Council of Social Agencies used data Irom 15 private and four public agencies to give some indication of the existing need. It was found that 144 families with 391 children needed some sort of day care. Later on in the fal1, a committee composed of two representatives of the six care work agencies studied the results. One of the recommendations made after the follow-up study was completed in December, 1941 was that at least two new chlld care units be established.

In May, 1942, the Council of Social Agencies, with the Superintendent of Schools made a survey of 14 schools in some of the 1 ess prosperous neighborhoods in New Baven. Questionnelres were recelved for 3,455 families with 6, 936 ohildren under 14 years of age; either the only parent in the home or both parents were working in 903 homes.

On the basis of these surveys the New Haven State Teachers' College, the Council of Social Agencies and the school system began to coordinate their efforts to meet the situation. Lanham Act funds were requested with the assistance of the Child Care Committee of the State Defense Council, which was formed in June, 1941. It developed that the Board of Education was the official sponsor for the funds, which it was learned in September, 1942 had been obtained from lasbington. About $\$ 15,000$ was granted with an equal amount expected from fees paid in by parents. It was necessary that a review of the plan be made and the application "procesaed" by the WPA. PolICles were established by the State Teachers' College and the Advisory Committee composed of members of social agencies and educators.

1 Ruth A. Matiroy, "Wartime Need for Day Care of Children;" The Family, XXIII (June, 1942) p. 123 
The Child Care Project had two distinct parts:

1) Day Nursery - Attended by 45 pre-school children and 20 children from kindergarten. The hours are 6:30 A.M. to 6:30 P.M., Londays through Fridays.

2) After-school oare - For 100 grade school children. The late afternoon program from 3:00 P.M. to 5:00 P.M. started on an experimental basis in october. 1

In May, 1941, the Community Organization Division of the Hartford Council of Social Agencies appointed a Committee on Day Care. To determine the need, questionnaires were sent to labor unions, the state employment office, public playgrounds and the social agencies. Later on, the form was published as a paid advert1sement in the newspaper. It was found that the city offered some type of day car service to 225 pre-school children in groups, and to fifty-one school children who received after-school supervision five days a week. The blanks distributed numbered 6,850 of which 144 were returned. Fifty replies on the newspaper form were received.

In March, 1942 the Committee on Day Care draw up a plan in outline form which included the essentials of an adequate day care program. Among other proposals it was suggested that the office of supervicor of child care centers be created by the Board of Education for the time the war would last and that a trained person be asked to fill the position. From the point of view of making full use of resources, it was advised that the Committee on Day Care be used as an advisory committee to the Board of Education.

\footnotetext{
1

"Development of New Haven Child Care Center," (New Haven Counc11 of Social Agencies, September 21, 1942) $3 \mathrm{pp}$
} 
At the beginning of the summer of 1942, the Board of Education hoped to open nine centers, depending on the number of parents desiring the servioe. The cost was to have been met by parents and funds supplied through the Lanham Aot. The proposed hours were 6:30 A.M. to 6:00 P.M. Monday through Saturday, with a maximum capacity of thirty and the fee of fifty cents a day. There would be two groups of children of school age; the six to nine year olds and chlldren in the ten to twelve year age group. Not more than 75 children would be cared for in one untt. The pees for this service would be thirty-five cents per day with individual adjustments made for families having more than one child admitted to the program. In December, 1942 Lanham funds had not been obtained so that plans could not be carried out but a re-application for federal funds was to have been made in a short time. 1

\section{Existing Local Facilities}

Mursery schools have a comparatively long history in the city of Louisvilie. It 1s said that the first nursery school opened south of the Ohlo river was begun in the George D. Prentice school building in the fall of 1927. As a preliminary to its establishment, Mrs. Lelia 0 . Leldinger, a member of the Board of Education, and Mrs. Adelaide S. Whiteside, principal of the Prentice School, spent the summer of 1927 studying the nursery school movement in Californie. Through thelr combined efforts the "Prentice Toddlers. School" was begun and has been in existence ever since. One room In the main building and a portable room were equipped by the Younger Woman's $C_{1 u b ;}$ a teacher was paid by the Lions' Club. Bince then the name

\footnotetext{
1 "Report of Committee on Day Care," (Council of Social Agencies of Hartford, August, 1941) $12 \mathrm{pp}$. and "plan for Care of Children of Working Mothers" (Committee on Day Care, December 1, 1942) 2.pp
} 
has been changed to the Prentice Nursery Sohool, and it has been operating under the auspices of the UPA. 1

A day nursery survey was made by the Family and Child Nelfare Council in 1928 in cooperation with the health council and recreation council at the request of the executive committer of the Community Chest. The sources of information were day nurseries, home visits, case-working agencies, schools and settlements.

It was found that during the month of October, 1928, 131 families with 157 children were given service. The local nurseries at that time consisted of the Bast Fnd Day Nursery, the Nest Bnd Nursery, the Union Gospel Mission, and the Prentice Toddlers' School. All of the nurseries were within a ten minute walk for $50 \%$ of the families. Domestic and factory work was the occupational field of most of the mothers. The majority or settlement leaders thought there was a need for additional centers but there were no figures to confirm this.

Several recommendations were made. Among then were that all admissions should be investigated by a trained caseworker and that regular registration should be made with the Social Service Exohange. It was decided that not more than eight or twelve "run-abouts" should be under the care of one attendant. ${ }^{2}$

In Apri1, 1930, a supervisor at the Family Service Organization

1 grelyn Adams, A Burvey of Locel Mursery Sohools, Play Sohools, and Private Kindergartens, Authorized by the Louisville College Club through the Day Care Committee and the Civilian Defense Council. (Loulsvilie, Ky., March 1, 1943) p. 1-9.

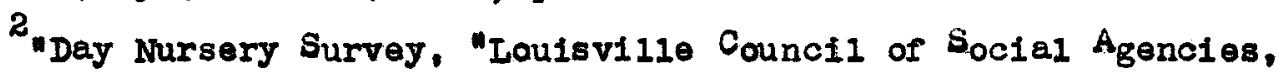
(1928) $2 \mathrm{pp}$. 
expressed concern over the number of working mothers in one of the two districts in the agency. Of 229 families active during April, 36 mothers were employed outside the home, of wich $16 \%$ hed one child under three years of age. Forty-three mothers were being encouraged to work; the supervisor was urging that the caseworkers adhere to the principle that certain dangers always accompany the mother's continued absence from home. I

Two directorles including a total of 25 sohools not included under the public or parochial school system were published in Maroh, 1943. The pamphlet, "Private Kindergartens, Nursery and Play Sohools" was published by the Loulsville Defense Council; the list of schools under the auspices of organizations was mimeographed through the courtesy of the Loulsville Councll of Social Agencies. Both of these were compiled under the auspices of the Loulsville College Club. Including kindergartens, the total number of units, both publio and private, were twenty-five; of these, 13 were private, 8 were sponsored by the WPA, 3 by the Community Chest, and 1 by the Counc1 of Jewish Women.

Only four of the sohools offered after-school care; three of these were under the auspices of organizations and one was a private nursery school. There was a great deal of variability in regard to attendance and fees. There was an average attendance in the 25 units of 369 children or 14.4 children per unit. ${ }^{2} 16$ of the total number of centers could expand plant facilities if the need arose. The fees could not easily be tabulated because of such factors as lunch, transportation, hours and

\section{1}

E. Glendenning, "Interpretative Report of Nestern District," (Louisvi11e, Ky., April, 1930) 3 pp.

Zivelyn Adams, A Survey of Local Nursery Schools, Play Sohools,

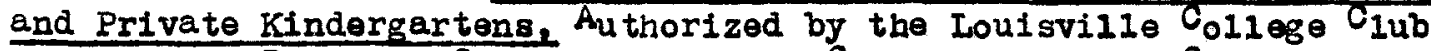
through the Day Care Committee and the Civilian Defense Counc11. (Louisville, Ky., March 1,1943 ) p. 3 
whether or not cots are required. The incomes of parents or the children who attended WPA schools veried from $\$ 50$ to $\$ 300$ per month. 1

The author visited all but one of the WA schools, the three centers sponsored by the Community Chest and the one under the auspices of the Council of Jewish Women, as well as one of the oldest private nursery schools. The author would disagree with Mrs. Adams on a number of points brought out in the latter's survey, in regard to standards maintained in the centers.

Although Mrs. Adams reported that all of the directors had special training in the field, in a number of cases it was known that this trainlng did not consist of more than a few weeks which is not sufficient time to qualify a teacher for her job. The bulldings were in fairly good repair, but there was much room for improvement. As Mrs. Adams brought out, each school had indoor and outdoor play space and all of them had central heating and modern conveniences. There was also a question in the author's mind about the consistency of well-planned programs in all of the schools. In one sohool visited, the teacher blew a whistle to quiet the children and apparentiy made little effort toward the last of the day (the time the visit was made) to carry on a program of any sort. In another school there was complete confusion and apparently little ability on the part of the teacher to direct the children's plans. A more favorable impression was made by the other schools in terms of their organization and personnel. On the rollowing page is a distribution map of the twenty-five nursery schools in Louisville. In the author's opinion, it is apparent that there is some duplication of service and wide areas that have no

2 Ibid., supplement 


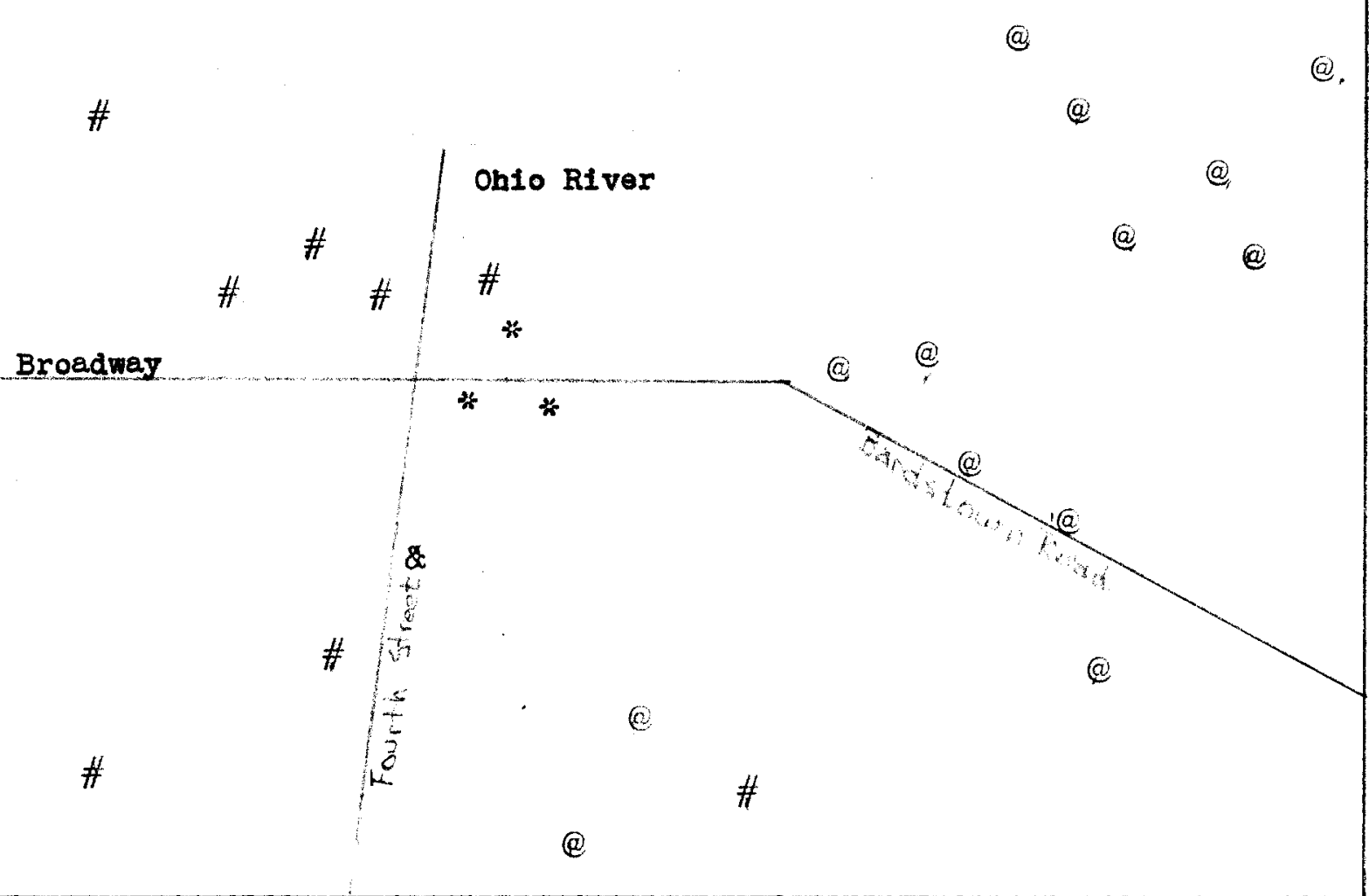

\section{IRARND}

13 Privato. . . .9

8 WPA. . . . . . \#

3 Community Chest...

1 Council of Jewish

Women. . . . . \&

1

Ib1d.., p. 4 
facilities. The central neighborhoods seem to have adequate coverage, as well as the northeastern district known as Crescent Hill, but the southern and extreme western parts of the city have been neglected. One of the newer schools at the Mackin Council is on 26th Street, but 1t is located too far north to be reached by many working mothers living south of Broadway.

Another lack of sufficient resources is in the group care that is provided for the children of Negro working mothers. These comprise a much larger group relatively speaking than do the white mothers but there is only one nursery school, located in the center of town to which Negro mothers may take their children for all-day care and another a few blocks away that is open from nine to twelve three days a week. This school admits only children of pre-school age.

There is much evidence to prove that social progress is often accelerated in time of war. This is true in the area of day care as is shown by the strides that were made in the months prior to the country's entrance into the war and the time that followed.

Perhaps most significant for the future of day care in the United States is the interes that has been indicated on the federal level. In the summer of 1941, the conference was held in Washington on the "Day Care of Children of Working Mothers" which served as a beginning in the planning for preparation for a manual of standards, general and speciflc suggestions for community activities, and the role that could be assumed by the national government to help solve the problems of the local communities.

Two federal programs of fering financing for day care needs were the Child Protection Program under the WPA and the program allocating funds to communities that could not finance their own services, known as the Community Facilities Act or the Lanham Act. The former had been in operation 
since 1935 and was aware and attuned to war-time needs; the 1atter was administered by the Federal Works Agency as a new program that could be approached through the welfare or educational ohannels. Another federal agency taking action in the day care field was the War Manpower Commission. Two directives were issued by this agency, one in regard to the employment of mothers in industry and the other in reference to the role of various nationel agencies in the day care set-up. To further the aims in this directive the President set aside $\$ 400,000$ in an emergency fund. A special section of the Orfice of Defense, Health and Welfare Services was established to deal with the problem of day care and act as a sort of "clearing house" for the other agencies.

England's experience has value for social leaders in America. The dangers and results of lack of planning in the beginning jears of the war are apparent and much may be gained from study of the present system in that country. Although many children are cared for in day centers, the "minders" similar to the famed "nannies" provide another form of service as we11 as the units that are set up in residences that do not admit more than ten or twelve children for full-time care.

Inherent in the problem of day care of the children of working mothers is the need for women in industry. That a certain number of women are needed to replace men that have been called to the armed forces, cannot be disputed, but it is doubtful whether or not it will ever be necessary to recruit women with young children for industry. In the event that it does become urgent that they go to work, it has been suggested that they work on a part-time basis, thus allowing them to cooperate with their neighbors in caring for each others children. 
The action that has been taken in five other cities: Hartford, New Haven. Cleveland, Seattle, and Minneapolis, in regard to day care is mentioned herein in an effort to present a sampling of work that is being done all over the country. Especially cities that have firms with large defense contracts have been concerned because of the tremendous increase in population that is common to defense areas.

Loulsville has thirteen centers operated by private funds, and twelve are financed by organizations. Many of these are located comparatively close together with the result that there are wide areas 10 ft with no resources. Many of the schools are attractive and no overcrowding was apparent. It is to be boped that with increasing community interest and the possibility of federal funds for the city, that standards can be raised in terms of personnel, programs, counseling, and better provision for the children of Negro working mothers. 


\section{CEAPTER III}

THE WORK OF THE DAY CARE COLMITTES OF LOUISVILIE, KERNTUCKY, FROM FEBRUARY, 1942 - MARCE, 1943. 


\section{Chapter III}

The Work of The Day Care Committee of

Louisville, Kentucky, Irom February.

1942 - March, 1943.

Louisville's awareness of the problem of day care for children was shown by the establishment in February, 1942 of the Day Care Committee. This was a sub-committee of the Family Security Conmittee of the Louisvilie Defense Counc11. The Day Care Committes had, from the beginning, attempted to discover the need, if any, for care of children of working mothers and to make plans for meeting the need. Its membership consisted of representatives from the Department of Public Welfare, the Work Projects Administration, the Board of Education, the Board of Health, the College Club, the Child Welfare Division of the State Department of Welfare, the Parochial Schools, a settlement house, a day nursery, and four Communtty Chest agencies: the Family Service Organization, the Children's Agency, the Mental Hygiene Clinic, and Neighborhood House. Membership grew as interest in the subject increased throughout the country and the community.

It was the philosophy of the Committee since its formation that the mother who was taking good care of her children was making a real contribution to the war effort. At the same tire, there was recognition of the fact that the need for more women in industry was increasing. Many of these were mothers of young children, making it necessary in many cases for the community to provide care for the children while the mother was out of the home. On the assumption that federal funds might be obtained to assist the local communities in this service, a number of surveys to determine the need were conducted during the ensuing months. 
The first survey undertaken by the Committee was made of women working in local companies that had defense contracts. An example of one of these firms which formerly met oivilian needs but had begun producing supplies for men in the armed forces was the General Shoe Lace Company which made shoe laces for service men. To obtain the names of these industries employing the largest number of women with children, several members of the Day Care Committee went to the Louisvilie Board of Trade and the United States Imployment Service. There were seven concerns that filled out and returned the questionnaires that were given them. These forms were given to the personnel directors, if the company employed one; if the company did not have a personnel director, the employer or person in charge of the office was se日n.

The committee members gave out the questionnaires and collected them. Questions asked on the blanks referred to the number of working mothers, ages of their children, working hours, approximate earnings and the director's opinion as to whether or not there would be an increase in the number of women employed during 1942. The information obtained was by no means complete, but the Committeo considered that the following facts were significant:

$\begin{array}{ccc}\begin{array}{c}\text { Women } \\ \text { omployed }\end{array} & \begin{array}{c}\text { Women with } \\ \text { ohildren }\end{array} & \begin{array}{c}\text { Anticipating } \\ \text { increase. }\end{array} \\ 58 & \begin{array}{c}22 \\ 200\end{array} & \text { Not known } \\ & \text { Yes } \\ 10 & \text { Not known } & \text { Possibly } \\ 14 & 2 & \text { No } \\ 75 & \text { Not known } & \text { No } \\ 2 & \text { Not known } & \text { No } \\ \frac{100}{459} & \text { Nes }\end{array}$

General Shoe Iace Co. Kane Manufacturing Co. Kentucky Tent and Awning Co. Louisville Tin and Stove Co Puritan Cordage Mills Shannon Spring Bed and Manufacturing Co. Wuest Bros. Inc. 
It will be noticed that in only two companies was a sizeable number of women employed. At the time the survey was made there were large defense plants employlng women but they were not hiring women with children and one of them would not hire married women. It is obvious, though, that in spite of the fact that the manpower shortage was not sufficiently acute in February, 1942 for a very large number of women with children to be employed, at the same time an incomplete picture of the actual situation was the result of the survey due to the lack of cooperation on the part of the personnel directors and employers.

Several weeks later an effort was made by the same members of the Committee and a volunteer to reach mothers employed in defense work through their employers or personnel director. Three of the companies mentioned above (the Kane Manufacturing Co., the General Shoe Lace Co., and the Puritan Cordage Milis) and five additional industries (the Von Allmen Preserving Co., the J.V. Pilcher Manufacturing $C_{0}$. , the Louisville Bedding Co., the Louisville Textile Co., and the Kentucky Macaroni $C_{0}$ ) were included in the study. The followIng results were obtained.

\section{Industry}

Kane Mfg. Co. General Bnoe Lace Co. Von Allmen Preserving Company

J.V.PIICher Mfg. Co. Louisville Bedding Co. Louisvilie Textile Co Puritan Cordage Mills $\mathrm{KJ}$. Macar ont Co.
Questionnaires Given out Returned

\begin{tabular}{rr}
200 & 4 \\
86 & 9 \\
35 & 8 \\
50 & 1 \\
100 & 12 \\
370 & 10 \\
75 & 0 \\
90 & 0 \\
\hline 1006 & 44
\end{tabular}

\begin{tabular}{cc}
\multicolumn{2}{c}{ Care Reported: } \\
Satisfactory & Unsatisfactory \\
4 & \\
9 & \\
6 & 2 \\
1 & \\
12 & 3 \\
7 & \\
$\frac{39}{39}$ & -5
\end{tabular}


The statistics from this study would indicate that the need for day care in Louisville was so small as to be practically negligible, but here again it was felt by the Committee that only a fraction of the picture had been obtained. They had some doubt as to whether or not all of the employers or personnel men gave out their questionnaires; at the same time they realized that many of the mothers probably hesitated to admit that the existing plan for their children was not satisfactory.

In the early part of the summer a settlement, Neighborhood House, made an informal study of the families immediately surrounding it. This was approached from the point of view of how the program of that agency could best adjust to the needs of the neighborhood. The staff member and volunteer by whom it was conducted did not use a formal questionnaire but they did ask each family questions pertaining to the employment of the mother, the provision she had made for her children at home, and whether or not the parents had any interest in the establishment of a nursery school in the settlement. Thirty-nine families were interviewed out of approximately eightyfive to one hundred visited. Although only six of the mothers were employed full-time, quite a few worked part-time and all of the thirty-nine indicated an interest in some type of pre-school care for their children. The two head residents of the settlement also believed there was need for day care in the neighborhood, because of the increase in the number of children of pre-school age who ceme to the playground and gave evidence of neglect. There was the possibility of another survey being made of the same area during the first weoks of 1943 to get some estimate of the changes that had occurred during the intervening six months. It was thought probable by the head residents that many more mothers would be working in the lower paid 
jobs which had been left by skilled workers who had gone into defense industries. An increased interest on the part of all concerned with the day care was thought to be inevitable, because even during the summer of 1942 the feeling was expressed along some of the women who belonged to the Mothers' Olub of the Neighborhood House that they felt inadequate to care for their neighbors' children, the parents of whom had been paying them for this service.

At the May meeting of the Day Care Committee, it was reported that a number of children were left unsupervised during the day in the housing projects. To investigate the possibilities of this being another area in which to explore the need, a survey was made in August of one of the white housing projecte, Clarksdele. Two social workers from the public relief agency, the Municipal Bureau of Social Service made house to house visits using the same questionnaires that was used in contacting the defense industries. The names of those visited were made available by the Municipal Housing Commission from their survey of income in January, 1942.

\section{Clarksdale Survey}

Chart Showing Number of Children According to Age Living in Clarksdale and Needing Day Care

\begin{tabular}{ll}
\hline Total & 18 \\
\hline Less than 6 years & 4 \\
6 years, less than 10 & 7 \\
10 years, less than 14 & 6 \\
Over 14 years & 1 \\
\hline
\end{tabular}


Out of a total of twenty-seven families, seven mothers with eighteen children were found to need care. One of the difficulties which became apparent in this and other studies made by the Committee, was the variation in the working hours of the mothers employed. Many of the industries doing defense work were operating on swing shifts, causing women to work on the late afternoon and night shifts. This necessitated planning for day care with a different approach. In this survey, three mothers worked from 7:00 A.M. to 4:00 P.M., one worked from 2:30 to 5:00 P.M. one from 2:00 P.M. to 10:00 P.M., and one from 4:30 in the afternoon to 6:00 P.M.., and one from 10:00 in the morning to 10:00 P.M.

Several situations in this study disclosed the need for assistance with day care:

Mrs. B. was employed on the night shift at a defense plant and her husband was a paper hanger. They had two children, ages seven and nine, who at present were viaiting their grandmother in the country. Ordinarily they had an elderly woman oare for the children but it was likely that she would not return. Mrs. B. was interested in day care for the children from 7:00 A.M. to 5:00 P.M.

"Mrs. H. was employed on WPA, and her husband was in a government hospital. She had five children, ages, 2, 5, 9, 11 and 15. Ordinarily Mrs. H.'s mother or sister cared for the children, but at this time the older ones cared for the younger children. Mrs. H. did not find the plan satisfactory and was interested in day care from 8:00 A.M. to 4:30 P.M. "Mrs. D. , a widow, was employed on WPA. She had a son six years old and a daughter eight jears old, who were cared for by a colored mald, 
but this plan was not satisfactory as maids were not found dependable. Mrs. D. was interested in day care from 8:00 A.M. to 4:30 P.M."

In three out of the elght homes indicating need, relatives had formeriy taken care of the children; in three others either a colored maid or older woman had been responsible for them; in another the two children, aged 12 and 13 had taken care of themselves, and in the eighth, the child was, previous to the survey, sent to a nursery school, but this was no longer possible. These plans of care for children of mothers who are working are typical of many in the community, in that care by relatives or maids seem to be the most popular methods used, in contrast to the few mothers who send their children to day nurseries or nursery schools.

It is very probable that there were more women employed in the Clarksdale Elousing Project than this survey indicates. The women might have been afraid that their rent might be raised, or even that they might be evicted, if they let it be known that they had employient. For these reasons, the number that was given in January undoubtediy gives an estimate that is too low of the number of women working in Clarksdale in August. From January to August there was a decrease of 59 to 27 working women which can be explained in part by the turnover of occupancy within the project.

About the same time that the Clarksdale study was finished, another survey was begun through the labor unions. This was made by the author and is presented in detail in the fourth chapter.

In September, 1942, at the suggestion of the Chairman of the Day Care Committee, a canvass was made to discover the need for daj care among the children of women working in the Hoosier Ordnance Plant in Charlestown, Indiana, a defense center about eleven miles from Louisvilie. Approximately 50\% of the 
employees were living in Louisville at that time, and the percentage would probably remain the same. The results of the study were brought to the attention of the Day Care Committes by a representative of the company's War Production Drive Committee, a group made up of both labor and administration, and has as its purpose the welfare of the employees. The line foreman who presented the results to the Comittee pointed out that the employees came from a radius of sixty miles; the average mileage driven per day by each car is three miles. In view of the increasing difficulty in securing adequate transportation, the most practical plan seemed to be to establish the new centers (if needed) in the neighborhoods from which there were the largest number of requests.

The questionnaires were given out by the foreman to the women while they were on the job. The purpose of the survey was explained in full and the women were reported to be very willing to give information asked of them and to be enthusiastic about the possibilities of day care for their children. The only women who returned questionnaires were those who wanted care for their children; there were 52 women who responded, with a total of 92 children.

The results of the survey show that the greatest need in Louisville is in Portland - (from Jefferson to the river on the north, and from 18th to the river on the south); Central district - (Irom Broadway to oak Street, and from Clay Street to 18th Street); and North Central district - (from Broadway to the river on the north, from Clay to 18th St.). It was found that seventeen mothers work on the shift from 7:00 A.M. to 4:00 P.M. (approximately the customary hours for a day center), but fifteen mothers are at work 
from 2:00 P. M., to 10:00 P.M. An equal number work from 3:00 P.M. to 12:00 P.M., and from 6:00 A. M., to 2:00 P.M. Thus, there is more need for a center that is open during the day, than for the other shifts, but if all the mothers are to be served some sort of care will have to be provided on a 24 hour basis. The table on the following page shows that the greatest number of children were under six years of age. There were fifty-two of pre-school age as compared with forty children over six. of the total group, there were fifty-one boys and forty-one girls. The ages of the children had a marked influence on the mothers' absences from work. Although the two-year-olds and six-year-olds have no effect (there were as many mothers said "yes" as "no") ten three- year-olds kept their mothers from work compared with three the same age who did not; in the four-year-old group this proportion was nine to seven; in the five-year-olds it was seven to four. More seven, eight, and nine-year-olds caused absences than those who did not, but after that age the ratio was either equal or inverse. This would indicate that the pre-school age children should be the first to have care, but there is also need in the upper age groups.

About two months after the survey was completed, the chairman of the Day Care Committee was asked to be present at the War Production Drive Committee meeting. Besides the representetives from the administration and the employees, there was a member of the Indiana Department of Public Welfare present. A great deal of interest in day care was evident, the women being particularly curlous about the type of medical care their children would receive in a day center. The chairman of the Day Care Committee of Louisville discussed with this committee the possibilities of allowing mothers with young children to work on the day shifts. At the time this did not seem practicable to the committee, but the idea was new to them and there was the chance 
Louisville Mothers Responding to the Day Nursery Questionnaire at the Eoosier Ordnance Plant, According to the Number of Children Two Years 01d and over in the Family.

\begin{tabular}{|lc|}
\hline \multicolumn{1}{|c|}{ Mothers Reporting } & Number of Mothers \\
\hline Total & 52 \\
\hline No children & 3 \\
One child & 18 \\
Two children & 22 \\
Three children & 8 \\
Six children & 1 \\
\hline
\end{tabular}

Table II

Louisvilie Mothers Responding to the Day Nursery Questionnaire at the Hoosier Ordnance Plant, According to the Mother's Working Shift.

\begin{tabular}{|c|c|}
\hline $\begin{array}{c}\text { Mother's } \\
\text { Working Shift }\end{array}$ & Number of Mothers \\
\hline Total & 52 \\
\hline 2:00 P.M. to 10:00 P.M. & 15 \\
3:00 P.M. to 12:00 P.M. & 9 \\
6:00 A.M. to 2:00 P.M. & 9 \\
7:00 A.M. to 4:00 P.M. & 17 \\
Unspecified & 2 \\
\hline
\end{tabular}

For facility of tabulation, shifts $7: 00-3: 00,7: 00-3: 30,7: 15-3: 45,7: 15-$ 4:00, 7:30-3:30, 7:30-4:15, 7:45-4:15 were all tabulated under the general range 7:00-4:00. Likewise shifts $3: 15-11: 45,3: 45-11: 45$ and $3: 45-12: 15$ were tabulated under 3:00-12:00. 
Table III

Children Two Years $01 d$ and Over Reported by Loulav111e Mothers Answering the Day Nursery Questionnaire at the Hoosier Ordnance Plant, According to the Ages of the Children.

\begin{tabular}{|c|c|}
\hline $\begin{array}{c}\text { Ages or } \\
\text { Children }\end{array}$ & $\begin{array}{c}\text { Number of } \\
\text { Children }\end{array}$ \\
\hline Total & 92 \\
\hline 2 years, less than 6 & 52 \\
6 years, 1ess than 12 & 32 \\
12 years less than 16 & 8 \\
\hline
\end{tabular}

Table IV

Louisville Mothers, Answering the Day Nursery Questionnaire at the Hoosier Ordnance Plant, Reporting Absences from Work, AcoordIng to the Number of Cbildren Two Years $01 d$ and over in the Family.

\begin{tabular}{|c|c|c|c|c|c|c|}
\hline \multirow{2}{*}{$\begin{array}{c}\text { Absent } \\
\text { From Work }\end{array}$} & \multirow[b]{2}{*}{ Total } & \multicolumn{5}{|c|}{ Number of Children in Fami iy } \\
\hline & & None & One & Two & Three & $\operatorname{six}$ \\
\hline Total & 52 & 3 & 18 & 22 & 8 & 1 \\
\hline Yes & 30 & 2 & 9 & 14 & 5 & 0 \\
\hline No & 22 & 1 & 9 & 8 & 3 & 1 \\
\hline
\end{tabular}


Louisville Mothers, Answering the Day Nursery questionnaire at the Hoosier Ordnance Plant, Reporting Absences from Work, According to the Family and According to the Mother's Shift.

\begin{tabular}{|c|c|c|c|c|c|c|}
\hline \multirow{2}{*}{$\begin{array}{l}\text { Absent } \\
\text { From } \\
\text { Work }\end{array}$} & \multirow[b]{2}{*}{ Total } & \multicolumn{4}{|c|}{ Mother's Dorking Shift } & \multirow[b]{2}{*}{$\begin{array}{l}\text { Unspeci- } \\
\text { fied }\end{array}$} \\
\hline & & $\begin{array}{l}2 \text { P.M. } \\
\text { to } \\
10: \text { P.M. }\end{array}$ & $\begin{array}{l}3 \text { P.M. } \\
\text { to } \\
12 \text { A.M. }\end{array}$ & $\begin{array}{c}6 \mathrm{P} . \mathrm{M} . \\
\text { to } \\
2 \mathrm{P} . \mathrm{M} .\end{array}$ & $\begin{array}{c}7 \mathrm{~A} . \mathrm{H}_{0} \\
\text { to } \\
4 \mathrm{P} . \mathrm{H}_{0}\end{array}$ & \\
\hline Total & 52 & 15 & 9 & 9 & 17 & 2 \\
\hline Yos & 30 & 9 & 3 & 7 & 9 & 2 \\
\hline No & 22 & 6 & 6 & 2 & 8 & 0 \\
\hline
\end{tabular}

Table VI.

Louisville Mothers, Answering the Day Nursery Questionnaire at the Hoosier ordnance Plant, Reporting Absences for Work, According to the Ages of Their Children Two Years Old and over

\begin{tabular}{|l|l|l|c|c|}
\hline $\begin{array}{l}\text { Absent } \\
\text { From } \\
\text { Work }\end{array}$ & Total & $\begin{array}{l}\text { Ages of Children } \\
\text { less than } \\
6 \text { years }\end{array}$ & $\begin{array}{l}6 \text { years } \\
\text { less than } \\
12 \text { years }\end{array}$ & $\begin{array}{c}12 \text { years, } \\
\text { less than } \\
16 \text { years }\end{array}$ \\
\hline \multirow{3}{*}{ Total } & 92 & 52 & 32 & 8 \\
\hline Yes & 52 & 32 & 18 & 2 \\
No & 40 & 20 & 14 & 6 \\
\hline
\end{tabular}


that this policy might be adopted at some future date.

The only surveys in this group that were made or Negro children needing day care were those begun by the Children's Division of the State Department of Public Welfare in November. 1 one of these covered the four blocks between 22nd and 24th Streets, and between Chestnut and cedar Streets. This area was chosen because it is a particularly highly populated neighborhood and would probably be one of the first to be influenced by the war effort. The incidence of juvenile delinquency is high in the neighborhood and there is a relative1y large number of children. To determine the length of time the mothers had been employed, the question "How 1ong employed?" was inserted after "llhat kind of work do you do?" on the same questionnaire that was used by the Day Care Committee in their survey at Clarksdale and in the defense industries.

Two volunteer workers made visits to all the families with mothers who worked who had children under eighteen within the four blocks. To obtain the names of these mothers, numerous inquiries were made of the families living within the district. It wess found that the majority of mothers were domestics doing either day work or house work. A number of others worked in laundries and restaurants, two were employed at the Quartermaster's Depot in Jeffersanville, Indiana, and one has worked for several years on a WPA sewing project.

Twenty-nine families with fifty-two children were interviewed. A special effort wes made by the volunteers to give the mothers assurance that they hoped the service of day centers could be provided if there was a need for them so that there was little threat to the famliies' security. As in

$1_{\text {The results were not available for the second survey made of a }}$ southwestern part of Louisvilie, when this study was compiled. It was later reported that in both surveys 226 children were in need of care. 
the Clarksdale survey, the value of the personal interview was 111ustrated as opposed to the indirect method of distributing questionnaires. The families cooperated willingly and every mother seen indicated destre for help in planning for her children. The problem of day care is one of long standing in the neighborhood; one reason being that it is customary for mothers to work to supplement the low incomes earned by the men in the family. Because of the tool of the personal interview and the attempt that was made to allay any suspicion, it was thought that most of the answers represented an accurate picture of the home situations. In the first survey twelve mothers reported their children to be left with relatives, seven said their children were cared for by friends when the parents were out of the home, one mother took her child to work with her, while eight stated that their children were left alone while they worked. There were thirteen in this group, the youngest of which was six, and eight out of the thirteen were over ten. This is an indication thet regardiess of how inadequate the care Is with relatives and friends, at any rate this survey does not show that any children of pre-school age are left alone.

It is to be expected that in a community such as Louisvilie, that is taking a vital part in the war effort that there would be some individuals who would want to help meet the changing needs in the locality and others who would seize the opportunity to commercialize on problems that result from the emergency. Women with both of these motives, or one or the other, have undertaken or considered undertaking setting up of a day center themselves. Those who came to the chairman of the Day Care Comittee for advice were strongly urged not to establish a center unless they were able to meet the minimum requirements for a good day center. Many of these women had no tralning, they 
had little conception of the tremendous financial requirements, or of the necessity of a large amount of equipment.

Members of the Committee became concerned about the number of day nurseries that did spring up wi thout license or trained personnel. A 11cense study was suggested since there was no state licensing law in Kentucky, and the ordinance that was passed in 1928 to affect Louisville had no meaning for Jefferson County. The title of the ordinance reads "An ordinance to license and regulate all persons, partnerships, associations and corporations establishing, conducting, managing or maintaining, In the city of Louisville, any boarding home for the care of children and placing the same under the supervision of the city health officer."

Several years ago the Department of Public Welfare became interested and cooperated in studying the situation with the Director of Health for Louisville and Jefferson County on the best methods of approach and the responsibilities of each department. In the November meeting of the Day Care Committee it was voted that a committee should be established to rewrite the City ordinance so that all foster homes, nursery and day care centers would be subject to licensing and inspection. It was discovered that it would not be possible to pass a city ordinance that would regulate county homes; this would have to be done by state legislation. Since the City and County Health Departments were coordinated, however, it was thought possible that the Director of Health might issue an order requesting that a11 homes for the care of children situated in the county must conform to those standards set up by ordinance in the city. 
Although there was no factual basis for comparison, social agencies reported an increase in the number of requests for day care information during 1942 over those of previous years. Two sets of these requests were compiled but it is doubtful that they were all included.

Telephone calls to the application department of the Family service Organization during the first eleven months of 1942 totaled thirty-three representing fifty-seven children. Twenty-three of these were under six years of age, but there were probably nore children of pre-school age than of school age because thirteen childrens' ages were unspecified. Seventeen of the thirty-three mothers were working, three were 111, one had another reason for wanting day care, and twelve did not specify their reason for their request, so that it is likely that quite a few more than half of the mothers were working.

Between September 1,1942 and November 30,1942 the Children's Agency had requests for care for twenty children. The entire group were under seven years of age and all but seven were under four. Within the next few months the number increased according to the executive secretary of the agency, but no formal record was kept. More and more people were also calling the Union Gospel Mission, a local day nursery asking for before and after-school care for their children. A resident worker stated in December, 1942 that if faollities were avallable seventy or eighty children would Immediately make use of them. Local churches and settlement houses also told of many mothers inquiring of them about day cere resources, and complaining that the hours of the existing nursery school facilities did not coincide with their working hours. 
Chart Showing Number of Children According to Age for whom Day Care was Requested at the Famliy Service Organization - January, 1942 - December, 1942

\begin{tabular}{|c|c|}
\hline Age & Children \\
\hline Total & 57 \\
\hline Less than 2 years & 13 \\
2 years, 1ess than 5 & 10 \\
5 years, 1ess than 13 & 21 \\
Unspecified & 13 \\
\hline
\end{tabular}

Chart Showing Number of Children According to Age for whom Day Care was Requested at the Children's Agency - September 1, 1942November $30,1942$.

\begin{tabular}{|c|c|}
\hline Age & Children \\
\hline Total & 20 \\
\hline Less than 2 years & 2 \\
2 years, less than 5 & 14 \\
5 years, less than 8 & 4 \\
\hline
\end{tabular}


A study of 28 working mothers with 87 children who were known to the Family Service Organization of Louisville, in November, 1942, showed that more than half of the children were cared for inadequately. ${ }^{1}$ Relatives or neighbors were chosen to care for the children not because of their ability or interest but because they lived near the family. Approximately thirty children manifested behavior problems ranging from very inconsequential ones to very serious difficulties. The ages of the children ranged from three months to twenty-one years; more than halr were in school. The reason given for the mother's employment was financial in every case. The father contributed in about half of the families and the mother's earning ranged from $\$ 4.00$ to $\$ 38.00$ per woek. The average time worked per week was fifty hours.

It was Interesting to note that the children in the Negro families were thought to receive better care than those in the white families. This might be explained partly by the fact that the colored families are accustomed to having the mother working; two of them used the East End Day Nursery. It is obvious that this study does not represent a fair sampling of the children of working mothers due to the fact that the families would not be known to the agency if the situation had not become so aoute that application for help with some difficulty other than the financial one. All but Iive of the families represented broken homes.

Wile each day center ideally has a tralned director or teacher at its head, there are many opportunities for the service of volunteers. The

"Marianna Lawson, "A Study of 28 Working Mothers" (Unpublished Master of Science dissertation, Graduate Division of Social Administration, University of Louisville, 1943) 
Day Care Committee felt that a group of these volunteer could be trained in five weeks to be better prepered for their work, and made such a recommendation to the office of Civilian Defense.

Much of the planning for these courses was undertaken by the Bducation Committee working in cooperation with the Civilian Defense Volunteer office. Three five-week courses were offered, the last one being completed the twenty-second of December, 1942. Two of them were for white women and one for colored. Applicants were between the ages of twenty and fifty, and a high school education was required. Classes were held three days a week and fifty hours' additional voluntary service was pledged. After the completion of the course and the service in training, the volunteers were expected to give one and one-half days a week to a local day center or nursery school.

The faculty for the course was composed of the director of a private nursery school, the nutritionist from the Community Chest, a WPA nursery school faculty member, the director of the infant and maternal welfare bureau for the Louisville and Jefferson County Health Department; director of the Children's Agency and chalrman of the Day Care Committee; the state director of WPA nursery education; the executive secretary of the Mental Hyglene Clinic; and the supervisor of nurses at the Children's Free Hospltal.

Approximately seventy volunteers completed all three courses. Many of them were placed in the local nursery schools, and by the end of 1942 the need in that area seemed to be met. Anotber such course was to be offered If there was the need for more volunteers. This was in line with the policy of the office of Civilian Defense which was set up to prepare people only for 
services that were in demand and would help during the emergency.

The Child Welfare Planning Committee of the Council of Social Agencies made the motion before the October committee meeting that the Day Care Committee apply for federal funds for day centers. A representative from the United States Children's Bureau was present at this meeting and told something of the situation in other localities, bringing out many dangers that resulted from not being prepared for an acute day care need. Shortly after this meeting, the Day Care Committee voted to apply for funds provided by the Lanham Act even though all of the returns had not come in from the various studies. The agency requests were not compiled, the union survey had not been completed and the State Welfare Department study had not been made. By the last of october, however, there were known to be 217 ch1ldren whose mothers were interested in group care for them. The total group included a baby three months old and others up to seventeen, but the largest number fell between the ages of two and five years.

The Committee decided that enough evidence was had to apply for funds from the Federal Government for four nurseries. Two of these were to be for white and two for Negro children. It was planned that they would care for children from two to five years and would provide both nursery school care and custodial care to extend the hours to meet the mothers' working hours. It was hoped that some of the schools would extend supervision to the school age child.

The request for Lanham Aot Iunds was not granted. A representative from the U. S. Office of Civilian Defense talked with the chairman of the Day Care Committee and said that he considered the prospects favorable of procuring the funds since the statistics had the actual names and addresses accompanying them. 
Later a member of the Children's Bureau and two representatives from the U. S. Offlce of Bducation met with the sub-committee of the Day Care Committee working on the application. It was the consensus of opinion that there was need for additional day care in Louisville, but emphasis was placed on the responsibility of the local community and in view of the fact that the War Fund went far over its goal in october, it was advised that the request go to the War Fund first.

In the interview the author had with the representative from the Children's Bureau, the latter brought out her belief that the need in Louisville was more or less a chronic one than one brought on by the emergency. If this were true the possibilities of obtaining the federal funds would diminish. Another subject discussed, was that of the approach in applying for the funds directly to Washington rather than through the State Department of Welfare. This had not been considered necessary since there was a member of the Children's Division of the state Department of Welfare on the Committee. In any event, the application had to be sent back to the State Department of Welfare for approval, before the Federal Government could take any further action.

It was announced at the January, 1943 meeting of the Committee that a sma11 sub-committee had made application for day care funds from the War Fund. Assuming that the centers would accomodate fifty children per day at an average of twenty-five cents per child, the total request was placed at $\$ 33,964$. The request was rejected. The Committee was not certain about the reason for this, but it was thought probable that not enough need in terms of numbers of children was shown and that the Board was hesitant to set up what appeared to them a new social agency that would continue after the war. 
The barriers were removed to some extent from obtaining Lanham Act funds when the need to show deficit financing in the local community was abolished in December, 1942. The following month the Day Care Comittee decided to make application through the educational channels, but proceedings could not be begun because the representative from the Board of Education on the Committes did not believe that sufficient evidence had been obtained to werrant application.

For this reason the Committee voted to ask for federal funds for an expert to make a scientific study of the need for day care in Louisvilie. At the next meeting this idea was discarded, because of the red tape that was apparently involved and the length of time that would be required to procure the expert. The best course seemed to be to have a survey made through all the schools in order to obtain a picture of the current situation. This play was carried out, but all of the results had not been tabulated for the public at this writing. On the basis of the studies made through the public and parochial schools, and the year's work done by the Day Care Committee, however, the Board of Education agreed in March, 1943 to make application for Lanham Act Iunds.

About this same time the 10 cal group of personnel men representing a large proportion of industry in Louisville began to take a very active interest in the care their women employees were being able to provide for their children, as an aid in helping them to declde whether or not they should begin to employ more women in their plants. This is a group that could be very instrumental in determining employment practices and making it posaible for such policies as women with small children to work only on day shifts, for instance. This same organization could include a large number of working women in a statistical survey that would be a valuable index to 
the local need for day care.

On the whole, the Day Care Commlttee in its first year of existence may not be said to have produced any singularly outstanding results. As far as statistical surveys are concerned, none of the studies was conducted by an expert, all of them covered samplings rather than any one entire area (with the exception of the Hoosier Ordnance Plant). The efforts of the Committeo to secure funds for the day centers from federal and local sources were only partially successful.

On the other hand, the Committee has a nucleus of Individuals, both lay and professional, who are interested in community welfare and have consistently contributed their knowledge and experience to the study of day care. The group may be justly proud of their efforts toward securing more adequate licensing laws for boarding homes and institutions. The community has been negligent in regulating standards for these homes. The subject of day care has been well publicized through the local newspapers. A member of the Louisville Courier-Journal staff served on the Day Care Committee. The Board of Bducation's decision to apply for Lanham Act funds was a most important step in the effort to establish day centers in Louisville. During the first six to eight months that the Committee was working, the representative of the Board of Education, who was in the field of secondary education, attended the Comittee meetings irregularly. It was not until late in the winter of 1942 that the Board of Education sent the person best equipped to deal with day care - - the assistant superintendent of schools whose work was principally in primary education. Moreover, it was necessary for the Committee to take all of the infiative in attempting to establish a relationship between the Board and itself. 
The extreme caution exercised by the Board of Fducation in relation to application for federal funds can readily be understood. Istablishment of day care centers under its sponsorship would necessitate much added responsibility and great expenditures of both time and effort. Also in the offing was the probability of many or a.1 of the WPA nursery schools being closed due to the termination of the WPA program; it is to be expected that one agency would be hesitant to take over that which another agency has begun.

The future of the success of the Day Care Committee cannot be predicted. It will probably act as an advisory committee following the establishment of day centers; this plan has worked successfully in other cities. In view of the composition of its membership of leaders in the community with their varied background and experience, it would seem that the group could offer valuable service in this capacity.

As far as the present need for day care is concerned in terms of work of the Committee, it is evident, in the author's opinion that Louisville needs additional day care facilities. The figures may not be as spectacular as those found in many current magazine articles, but there is every indication that the problem is one of long standing, aggravated by war conditions, and is actually being brought to light for the first time to be attacked realistically by those who have the ability to make effective changes. 
CEAPTER IV

THE SURVEY MADE THROUGE THE LABOR UNIONS 
Chapter IV.

The Survey Made Through The Labor Unions

The purpose of this study made through the local labor organizations was primarily to complete the picture of the need for day care in Louisville for the local Day Care Committe日. Up to this time, the fall of 1942, only a few surveys had been made and IIttle conclusive evidence had been obtained. The study was made by the author in cooperation with the chairman of the Day Care Committee. As far as could be ascertained, there had never been a. similar survey made within the unions in the community, so that most of the research was done by trial and error rather than methods that had been used before.

It was obvious that not alI of the union membership could possibly be covered by such a survey as this. As a groundwork, two leaders in the Workers' Education Council were interviewed regarding the whole labor setup. One of these women was a philanthropist, interested in fair wages and hours. It was she who recommended an interview with the editor of a labor column in the evening newspaper. She knew the kind of information that would be most likely to interest those associated with organized labor and what type of publicity would be most valuable. She produced a number of names of unions and leaders that would probably be cooperative.

The representative bodies of both the A. F. of I. and the CIO were addressed in an effort to gain their approval of the plan before individual leaders were seen. Permission was obtained to speak from officials within each group. The Central Labor Union composed of representatives of the 
American Federation of Labor, was attended by the author and a private nursery school director. The latter interpreted the meaning of the term "Day care" and told of the purpose of the survey about to be begun. Approximately fifty members attended the meeting. Most of the discussion centered around suggestions for publicizing the study, rather than any definite plans which might be carried out by the local unions to cover their membership. While the idea was not actively opposed, there was littie actual enthusiasm expressed on the whole.

The reaction was different as the plan was presented in the same way to the City Council, the representative organization for the Congress for Industrial Organization. The group was much smaller and more compact and a great deal of interest was shown as evidenced by the comments that followed. Concrete plans were made for beginning the survey; one official made the motion that each local union take the responsibility for mimeographing the questionnaires that would be needed. The motion passed and questions from then on centered about community facilities, the role the federal government was taking toward helping local communities provide day care, and the actual costs that would be assumed by families. It seemed to be the consensus of opinion that the best avenue of approach to the individuals would be through personal interviews with the heads of the unions or failing that, to contact them by letter. A personal interview would be difficult because of the fact that all of the head officials were employed in regular jobs, and could hardly be seen during working hours.

The survey was well publicized.

"With Labor's Ranks" in the Louisvilie Times, urged cooperation of the locals in procuring accurate data. Emphasis was placed on the fact that no pledge was involved. "Labor leaders made it clear (at the Central Labor Union meeting) that the workers 
who sign the blanks are not promising anything. The answers are used only for information." "Another question asks if the family could pay anything toward the upkeep of such a center. This does not mean that the man or woman who signs the petition is signing any money away. It is asked because many comparatively comfortable families would be glad to pay something toward the day care of their children, especially if payment makes it possible for other centers to be opened in poorer communities." 1

The Kentucky Labor News, a publication of the Americen Federation of

Labor, carried an editorial as well as a news item. The editorial ran as

fo110ws:

"This was must be won for our children. Few of us, now engaged in this war, will enjoy the benefits which we are fighting to preserve. We will gladiy derend the principles of this nation, with personal gain, because we sincerely desire to leave to our children an inheritance of freedom. We are actually in this war to give children a better way of $11 f e$. Once we grasp that truth, then we begin to understand what is essential to actually win this war. We must not only defeat the invader from without our country, but we must also protect our children from the evil forces which can destroy their morals. . .

"In order to build the equipment necessary for our armed forces, it has become necessary to enlist our women in industry. They have been forced by patriotic zeal and financial necessity, to leave their children in the care of other people or without care of any kind. - . Our government recognizes this condition and sincerely wants to do something to prevent a moral defeat. Money is available from the government for the establishment of centers for the care of children whose perents are in defense industries. The task of determining the number of children who will need this essential supervision has been placed in the hands of the Day Care Committee of the Louisville Defense Council. This agency works without compensation, but realizing the importance of the responsibility which has been delegated to them, they have set about their task with earnestness and genuine sincerity.

"One of the oddities of buman nature, is that we are skeptical of the motives of strangers. Their cause may seem good, yet we wonder if there is not some sinister reason behind their apparent altruistic effort. . . The chlldren can receive the proper care as soon as the government knows how much money is needed. It is time now that organized labor assist this agency. . .

1.U.S. Funds for Day Nurseries Depend on Survey" from the column, "With Labor's Ranks," The Louisville Times, October $2,1942$. 
"Organized Labor is the one agency which can best help in getting the information and co-operation which this agency needs. We are asked for that help because the agency itself recognized that we are in a position to enlist the working people in this vital cause. We must do this job. The future of America, and of decent civilization, depends upon our children. We must not negleot them for in so doing. we can lose this war more truly than would be suffered through military defeat." I

The questionnaire which was used was prepared in collaboration with the secretary of the Central Labor Union and the statistician of the Community Chest. It was slightly different from the one distributed by the Day Care Compltee in the Defense Industry Survey. On the union questionnaire the name of the firm in which the individual was employed was omitted as well as the kind of work done and the questions that asked, "Are you satisfied with the care your children are having while you are working?" and "If not, do you want help in planning for your children's care?" These were omitted in an effort to avold any defensiveness. It was thought that there might be the possibility of objections to disclosing the name of the firm for which one worked as well as the kind of work done, and that these two items did not have special significance for the study. A different set of questionnaires was made for the unions in the A. F. of L. from those of the CIO in regard to the organization that had given its endorsement to the study.

The question was added, however, that inquired as to whether or not the parent would be wllling to pay something for the children's care in a day center. This was put in in an effort to obtain some idea of the relative maintenance costs of operating a day center. The introductions to the questionnaire were similar, with two sentences being added to the union form: "The federal government has set aside funds for this purpose but it will be

"our Children Can Be Lost During the War," editorial, Kentucky Labor Nere, October 1, 1942 . 
necessary to gather this information before such funds can be used for Louisville. You may be certain your answers are confidential and do not obligate you or your family in any way."

The survey of the need for day care among the families of members of CIO union was made in approximately four weeks. Most of the preliminary work was done with the help of the secretary of the Textile Workers' Union. It was she who knew the officials in other CIO unions and the probable amount of cooperation that could be found in each local union. It was decided after talking with her, that to obtain the widest coverage it would be advisable to give questionnaires not only to the union women who were working, but also to try to reach the women whose husbands were union members and were working themselves.

One local union requested that they be given an explanation of the study and suggestions as to methods of participation; the author made an informal speech to this effect. The membership was composed entirely of women who worked in a nearby woolen mi11; approximately thirty were present, many of whom said that they knew of a number of women who needed to make immediate plans for their children and would welcome any plan that might eventually help them. They would mimeograph their own forms and see that they were distributed by the stewards at the mill. During this process someone among the workers started the rumor that in the event the questionnaire was signed the mother was in danger of having her children taken by the Juvenile Court. Before the rumor was begun 28 blanks had been filled in, with 21 of them indicating need, but the rest became suspicious and would not give any information.

Th1s union with the other two 10cals made up the Textile Workers' Union and probably comprised a larger membership of women than any other one 
union. The organizations in the other two mills reported no success, because of strained ralations with union headquarters and with the employers so that further efforts to canvass them seemed futile. The author did think, however, that there might be value in visiting some of the stewards in the first mill to see whether or not some follow-up work might be done. Each steward of the five that were interviewed in their homes had a similar story to tell. She did not know who had started the rumor; she thought there was a great deal of need for day care planning but she also thought it would be pointless to attempt to continue the survey in the mill, because the chances were too great that there would be no participation.

The United Auto Workers accomplished more on their own Initiative than any other union. A copy of the questionnaire was mailed the head, who had enough mimeographed to cover the entire union. flach member received a blank with instructions to take it home and fill it out if his wife was working, whether she needed care for their children or not. Only one questionnaire indicated need, but 5 were brought to the author by the head and the attitudes and opinions of the members were discussed in terms of interest in day care, adequacy of local facilities and the rising need for women in industry.

Representatives of the American Communications Workers, the Journeymen Tailors, the Utility Workers Organization, the Amalgamated Clothing Workers, and the Stete, County, and Municipal Workers' UnIon were all interviewed in person. Questionnaires were not made for any of these groups because of various reasons. The Journeymen Tailors and the State, County, and Municipal Workers did not have members who would be likely to have children at home under eighteen; ; their rolls were made up of middle-aged and older men and women. The American Communications Workers, a very small union, being 
composed of under a hundred people, had few married persons enrolled and a fairly large turnover due to induction so that even though there were several mothers working it was not thought worthwhile by the secretary to give them the blanks.

The organizer of the Utility Workers' Organization (a colored union), thought that there was undoubtediy need for day care among many of the wives of his members, but no results were obtained. The union was a new one to come to the Council; there may have been many practical difficulties in reaching the members. The person in the office of the Amalgamated Clothing Workers' Union did get in touch with a number of the men and women in this union, but reported that they were united in the opinion that "woman's place is in the home" and they did not approve of group care for children.

The two other unions in the City Council were the National Maritime Union and the Steel Workers' Union. The former made an attempt to contribute results to the survey by mimeographing questionnaires, but out of a membership of several thousand only thirty were returned and these were never seen by the author. They were lost when the union moved its office from Jeffersonville, Indiana, to Louisville. The man who gave the report on the results thought that there were approximately two children to each family that indicated a desire for day care. In the case of the Steel Workers' Union, there were completely negative results since the organizer could not be reached in person or by telephone and he did not repiy to the three letters that were written him by the author. In a.1, fifty-two mothers stated that they were in need of day care as far as could be ascertained through the clo workers. The number 
is not large, but one must remember that comparatively speaking, the City Council's organizations do not have a very large number of members affi1iated with them.

The secretary of the Kentucky Federation of Labor was not optimistic about the outlook for the survey. He pointed out the other pressing activities of the labor leaders and their unions and the novelty of the undertaking. Nevertheless, he admitted that the results might be interesting and volunteered the names of officials heading approximately three-fourths of the A. F. of I membership, many of which were included in the list given to the author by the nowspaper columist some time before. In the event some of the local unions should request a talk on the survey at their meetings, he thought these might be helpful.

There was no particular order in which the officials were seen. It was apparently most difficult for them to schedule definite appointments, so that the person who found it most convenient to discuss his 10cal's undertaking the survey was seen first. More often than not this would be the business agent, but in some instances it would be the secretary of another officer employed by the union.

Twenty-four A. F. of L. unions were included in the survey. In every case but one a representative was interviewed personaliy by the author, two unions asked for explanations at their meetings, and fifty mimeographed letters were sent to the smaller unions listed in the 8tate Federation of Labor office. If responses could have been obtained from all the members that the author attempted to reach indirectIy, replies would have been received from 75,000 people according to the secretary of the Kentucky Federation of Labor. 
The two meetings before which the author spoke were quite different In size, procedure and their reception of the plan. The presiding officer of the painters' Union requested that the idea be presented to the group without a personal interview with him beforehand, with the result that in the midst of mucb formality in the actual meeting there had to be clarificam tion of the part the union could take and little time for the men to express their opinions was left. Approximately three hundred members were present which was only a fraction of the total enrolied. Apparentiy no action was ever taken, although it was decided at the meeting that the blanks would be mimeographed in the office and sent out by mail. The presiding officer gave pressure of other work as the reason.

The Firemen and 0ilers' Union was much smalier and much more informal. Not more than thirty-five members were present and quite a lively discussion ensued after the author's speech and the presiding officer distributed questionnaires that had already been mimeographed in the business office. Several of the men had a real interest in some of their friends' children who were not receiving proper care and lived too far from a nursery school to make use of their services. The forms were given out to a presumably large percentage of the members who were not at the meeting, but only 5 were returned and of these 2 indicated need for help in planning for their children.

Representatives of $24 \mathrm{~A}$. F. of L. unions were interviewed; all but one were seen in person. There would be little value in reviewing each interview in detail, but a brief account of each of the officials' reactions may throw some light on the results that were obtained. 
Mr. B. of the Allied Printing Trade, had a great deal of difficulty in understanding the purpose of the survey. He preferred to present the plan in his meeting, before having the questionnaires mimeographed. The interview was necessarily brief because of a funeral which Mr. B. felt he should attend. He was not very optimistic because he said that most of his members were too old to have children under teen-age, nor did he have the Impression that many of the members' wives worked.

The Aluminum Workers' head, Mr. D., broke three appointments before the author finaliy was able to see him. He felt that there might be a real need later on, but at the time of the survey there were very few women members. He did discuss the study with his group and it was decided that the author should talk with one of the stewards who had been the most interested. The steward knew of several women who needed day care planning immediately, but did not seem to know exactly how she could proceed in relation to uncovering the need among the women with whom she worked. Suggestions were made by the author, and questionnaires were given her but she did not send in any results.

Mr. B. of the Boilermakers' Union was quite curlous about the questionnaire. He thought that the best method of contacting his membership would be to discuss the survey in his meeting and then have the stewards distribute the blanks. As he did not telephone the author as had been arranged, another call was made to his office. He said that when he went to the meeting to present the plan, not one of the members appeared. He had posted the questionnaire on the bulletin board of his office with an explanatory memo accompanying it. 
Mr. G., the leader of the Brewry Workers' Union that met twice each month and unless a member attended one of these meetings, he was required to pay a fine. Mr. G. insisted that he address both meetings before and funds be spent on paper for mimeographing the question forms. He was perhaps the person who was most pessimistic, on the whole, about the survey. He was concerned about the possibility of overlapping - wouldn't it be likely that his wife and child would be approached on the same subject? Furthermore, he did not think that union members, in general, tended to cooperate and was of the opinion that even a fraction of the complete picture of the need of day care would be impossible to obtain. According to Mr. J., the Builaing Service Imployees' Unton was one of the best organized, and since his stewards were paid for the union work that they did, he thought it would be comparatively simple to get in touch with the membership. He believed that the questionnaire was the sort that would be most likely to be answered fully, since 1t was brief and easily understood.

One of the largest unions in the whole group was that of the Carpenters' Union by Mr. B. He could send questionnaires to at least 5,000 families, and felt that this would be a better approach than merely attempting to pick out those members whose wives were employed. Mr. B. was the first official that was interviewed who had heard about the survey, having read about it in the Kentucky Labor News. It so happened that most of his members were pald quite adequate wages and few of them had wives who worked. Another person whom it was very difficult to see was Mr. G., of the B Class Carpenters' Union. He was quite realistic in that he had recently attempted to get word to his membership concerning some information that they had not had for their meeting, and had failed almost completely. He stated that "at best, they were not very cooperative." His was one of the smaller 
unions; there were comparatively few people to do the tremendous amount of clerical and administrative work that even a small union requires.

Mr. W., headed the Colored Waiters' Union, a full-time job as a waiter at the same time. It was his 1 dea to post the sample of the question blank on the headquarters' bulletin board, meanwhile he would have additional copies made and distributed to his members in the next few meetings. It was Mr. H. 's opinion that there would be a great deal of need among the members of his local because of the lack of facilities for the children of Negro working mothers.

Mr. MaK., Dist111ery Workers' Union, asked whether or not the survey was being sponsored by the Community Chest in connection with the Louisville Defense Council and seemed to have knowledge of the social agency set-up. He objected to the mimeographing since his secretary was new and pointed out that he spent most of his time out of town. He made out a list of the local unions that were in his organization and said that the only way to reach them was by correspondence. This was another union In which the men were adequately paid and very few of their wives working. The main point of concern with Mr. H., Blectrical Workers' Union, was that Louisville was not keeping pace with other cities its size in meeting the problem of the need for additional day care racilities. He had had several members come to him and ask him where their wives could leave the children during the day. He had told them that he did not know of any day centers in their neighborhoods, which had been in the southwestern part of the city. It would be difficult for him to tell many members about the survey who did not come to the meeting, but he promised that he and his secretary would do all that they could to cooperate. 
Mr. O. was employed by the Firemen and Oilers' Union, one of the unions before which the author spoke. He seemingly had no difficulty in having the questionnaire mimeographed by his secretary and thought that there would probably be quite a bit of need among the wives of his members. He was interested, too, in the work of social agencies and thought that such a survey would be valuable.

The Hodcarriers' Union, which Mr. L. headed, was the other Negro one in the group. His work takes him out of the office most of the time, so that it was almost impossible to talk with him by telephone or personally. There were undoubtedly many women working whose husbands were members of the union, but $M r$. L. believed that most of them had probebly made arrangements for their children that were satisfactory. Many of them stayed with relatives or neighbors. Perhaps some of them would accept and make use of additional group care centers; at any rate, he would make an attempt to measure the interest in his organization.

Mr. D., of the Ironworkers' Union, brought out his suspicion of the failure with which the survey would meet among his men. He felt that they would not want to sign their names, that they would probably shy away from the question regarding fees and that they would more than likely refuse to cooperate because the whole idea would be so new to them. He approved of the city's establishing new centers if they were needed, but he did not think that his union would have much to contribute to the statistics on the need for them.

The secretary of the Kentucky Federation of Labor recommended Mr. K., president of the Laborers' Union, as being a person who would want to help with the survey, and leading as large a union as he did, he would have a large field to cover. Mr. K. was not at all enthusiastic about the study. 
He did not think that many of the members earned enough to pay anything for the day care of their children and he doubted that the government would supply the funds for care in these instances.

Not a very large fraction of the members of Mr. M.'s organization, the Machlnists' Union came to the meetings, according to Mr. M., and his two assistants who were interviewed. There is no fine if they do not attend, and $\mathrm{Mr}$. M. had found that unless there was something that directly concerned them or their jobs, they did not feel compelled to attend and usually didn't. For this reason Mr. H. was quite dubious about the outcome of the survey, but agreed to discuss it with the membership that appeared at the next two meetings after the interview.

A11 of the stewards are paid in the Meatcutters' and Butcherworkers' Unton, of which Mr. S. was the head. He could give assurance that all of the members would be told of the survey and although he did not think that there was very much need for day care at that tIme, he had heard several men talking ebout their wives' considering employment and he was certain that they would want adequate care for their children if they did decide to work. He did not have time to ask the questions he would have liked to ask about the study, but he gave it his hearty approval. Mr. S., Milk Fagon Drivers' Union, thought that many of the men who might have been able to be quite helpful in making the survey a success in normal times had more than they could do in time of war and pointed out the time that was required to carry on the drive to collect scrap iron that had been delegated to the organized labor groups. Mr. S. was an active leader in the Central Labor Union as well as the head of his own union, and had a good understanding of the purpose and scope of the study of need for day care. 
Most of the work that was done by the author with Mr. P.'s union was done by his wife. There were no women who were members of this organization, but quite a number of the members' wives had small children, and worked. It was not convenient for Mrs. P to learn to mimeograph, so it was decided that the author would make the question blanks and the union would furnish the paper. Mr. P. thought it preferable to distribute them at the union meeting rather than give them to the stewards to give out. Mr. O'B., of the Steel Workers' Union, seemed to have a great deal of blocking on the idea of the survey as a whole. He was extremely busy at the time of the interview, but since the other unions that were in the Central Labor Union had offered to participate, he was anxious that his group have a part, but he was not at all optimistic about the final results. Being publicity man for the Tobacco Workers' Union was Mr. M.'s job. He was another person who knew something of the national problem of day care and was of the opinion that Louisville might be behind other cities of its size. Mr. M. had just come to Louisville a few weoks before and had a perspective on the labor situation that was wider than that of many of the other leaders. He was very enthusiastic about the survey and thought that the results should be very enlightening. He was 11 kewise interested in improving the relationship between labor and the social agencies.

My interview with Mr. A., Truck Drivers' Union, took place over the telephone. He was one of the few men who expressed the belier that women might be needed in the labor market to the point of their being drafted for duty. He thought that the problem of day care should be approached from the national angle; much higher standards could be maintained in this way as well as more efficient administration. He would present the idea of the survey to 
the members at the neat meeting and have his secretary call the author if there was surficient fiterest to warrant mimeographing blanks and distributing them.

1rs. H. of the Hotel and Restaurant Workers' Union, felt that since the membership of that union was so small (75 were enrolled), there would be little they could contribute. She thought it possible that some of the waitresses who had small children at home might be interested in the establishment of new centers. She thought that the subject could be included on the program of the next meeting.

Four of the unions that were thought to be especially likely to have some need for day care were written letters urging cooperation by the newspaper columnist who had publicized the survey several weeks before. The letters were sent after the author had explained the study to the leaders in person. The content of the letter was as follows:

"I am writing to ask you to be kind enough to give your special attention to assistance of the survey on the need of the establishment of child centers for children of working mothers.

"I am almost sure that we will have to get the bulk of our information through your union, the Hod-Carriers' Union and the Waiters' Union if nurseries are to be set up and ready to take care of the children when the demand becomes greatest. I have been talking to some women who have been trained as single process machinists and are working now. Those who have children have in each case employed a colored woman to $100 k$ after them during the day.

"The social organization in charge of children's aid report that good foster homes in which they can place children are already difficult to find.

"Will you try to get the question blanks to the workers on all your jobs? I am sure that they will not be filled in and signed unless accompanied by a statement from you or someone else the men trust, assuring the men that in filling in the blanks they are simply stating facts and not signing vague promises for the ruture. 


\begin{abstract}
"This is the situation. The United States Government has voted money for use in the care of children of working mothers in defense centers. This need not be confined to the children of mothers who are working in defense industries. Louisville will get no share of the money unless it is able to show the need. The question blanks are being sent out through the unions (after failure on the part of many managements to cooperate) and are to be collected, tabulated and sent on to Washington as a basis in requesting funds.
\end{abstract}

"When and if the funds are obtained, day nurseries. . and recreation centers are to be set up under a committee of very able and experienced women. Mrs. Sawyer, who visited the Central Union and obtained its endorsement, is one of them. There is no doubt that under the present set-up the funds would be handled well...

"I have been told that the National A. F. of I. has endorsed this survey and that Mr. Green wrote Mr. Weyler (secretary, State Federation of Labor) asking for labor's support." I

Another form letter was written by the author to the smaller unions picked at random from a larger list compiled in the Kentucky Federation of Labor office. Approximately fifty of these letters were sent out shortly after the personal interviews were completed. Enclosed was a post card addressed to the author on which questions were asked pertaining to the size of the union, the number of women in the union, the number of men in the union with wives who worked, and whether or not more women with children might be known to the union in the next few months.

One of the postcards was returned revealing that there were fifty members in the union, none of which were women and none of which had wives who worked. It was not thought likely that any of the members would be going to work in the near future. Another telephone call was recelved informing the author that the official to whom the card was addressed had

1

Letter written by Miss Ethel DuPont. 
moved out of town.

The results of the study throughout the A. F. of L. unions were almost completely negative. Out of 5,000 questionnaires given out through one union 10 were returned and three indicated need for day care; out of 700 distributed through another group 30 mothers wanted help with their children's care, according to the head of the union, and of 300 sent to another group, three blanks were returned showing need. Altbough no need was shown in one of the smaller unions, five questionnaires were returned out of the 500 distributed.

With few exceptions, the officials interviewed had preferred that the author wait on them to call about the progress that was being made in their own union in regard to the survey. When nothing was heard from them, numerous telephone calls were made and in some cases another call to the office.

Approximately six weeks after the actual survey was begun and it was evident that little or nothing had been accomplished as far as coverage was concerned, the secretary of the Central Labor Union suggested that another talk be made to that group. This suggestion was carrled out by the author and various reasons were given for the delays on the part of the officials. The presiding officer of the meeting thought that the best plan was to contact the men I had seen personally by calling them once more on the telephone and asking for definite information. He brought out that it was likely that few people present at the meeting were the same people who had been seen individualiy.

The complete 11st of people who were seen at first were finaly reached by telephone. The above statistics were the result. Some said that when the question had been brought up before their meeting, there had 
been no interest expressed, others found other union activities particularly pressing at that time, so that they did not have the time they had expected to have to put on the survey, another reported suspicion on the part of his membership and his consequent inability to carry the study any further. A number of the groups said that if they did have a large number of working mothers known to them, the children were being cared for adequately by relatives or neighbors.

One opinion that apparently is fundamental to the whole question is the fact that organized labor and the social agencies are poles apart. One leader apologized on the part of labor for its narrowness, saying that too of ten the men who were most influential in the unions were those who were concerned almost entirely with wages and hours, extent of membership and matters that pertained to the union. He continued that there were too few people in the key positions locally who really applied themselves to their work. Many of them had been in their organizations for such a long time that they did a minimum of work and they thought and cared little for community relationships. He did not think that labor was entirely to blame, however, for the breach and said that social agencies had a long way to go in recognizing labor as an integral part of the community and including it in its planning.

It is impossible to measure accurately how many working mothers learned of the day care survey made through the labor unions. In the first place, the method used of informing them of the survey was necessarily extremely indirect. If, for example, a union member heard the author speak at his union meeting, he could tell his wife of his impressions of the survey, but if the union was one where the author had a brief interview with the business 
agent, the interpretation of the survey might have to be made by the secretary in the office to the steward who would distribute the questionnalres to the men with bis own explanation. By the time the information reached the union member's wife, if at all, there would be many opportunities for error and distortion.

Interviewing officials of the unions who had not been present at the meetings of the Central Labor Unions and CI0 City Counc11, when the survey was endorsed, left opportunity for suspicion on the part of the officials in spite of the written endorsement. No more than two or three of the 25 men had been present at either of the meetings.

A more persistent approach might have been used to good advantage instead of leaving it up to the union head to get in touch with the author. Although all of the interviews were following up with other visits or telephone calls, a period of two or three weeks elapsed before these visits or calls were made.

It is obvious that a problem such as day care which concerns the welfare of the union membership is not one of the primary concerns of organized labor. The suspicion that labor has of social agencies is an important factor as well as the suspicion that is generally felt toward a survey in which one is asked to sign one's name. There is the possibility that more cooperation might have been evidenced if the request to give the name and address had been omitted along with the question regarding fees.

As a southern community, Loulsville has had the pattern of individuals hiring Negro maids to care for their children; in the event that their income did not permit this type of care, children are for the most part left with friends and neighbors. As unsatisfactory as this may be, parents seem 
to prefer it to group care which is a comparatively new service to many neighborhoods. The sensitivity that is felt on the part of a group of mothers that some agency might take their children from them is 1liustrated by the incident in the mill that caused the survey there to cease soon af ter it began.

One of the positive aspects of the survey is that the study may serve as a basis for further surveys in terms of methods of approach and planning. The method of interviewing the main officials seems to be valid; the question of the best methods of following up interviews is a matter of conjecture.

Albert Deutsch, in his article, "Get Together, Labor and Social Work," attempts to analyze some of the reasons for the condition that exists not only locally, but nationally. The difficulty originated years ago when labor saw social work grow from aristocratic charity and work hand in hand with capitalism. The worken were naturally suspicious and resented the paternalistic attitude that was evident. Charity came to mean money deducted from their pay envelopes and handed back to them as a benefice. The emphasis on morals and the organization of social agencies against trade unions did not improve the relationship. It was also noticed that private social work asked the rich for funds on the basis that their profession kept the poorer classes satisfied and suppressed revolutionary tendencies.

Toward the end of the last century, some of the more progressive unions began their own social planning in the areas of old-age pensions, sickness, disability, death and unemployment benefits. They did not wholly trust the settlement workers who went to the slum to live with the people they were going to work with. 
Professional development of pald workers in the social field began to break down some of the barrlers. Real problems were seen as such facts were learned about rents, profits, and living standards. Poor people were seen as individuals; a purpose was understood for labor organization. In the first decade of this century some converging of the paths of labor and social work was begun. Legislation required the efforts of both groups in housing, child labor, minimum wage and hours and general factory legislation. Some suspicion still exists, but "labor now recognizes social work as its loyal and most valuable ally in its fight for better conditions. The ultimate goals of both fields, - broadiy speaking, to reach the optimum in living conditions for the great masses of the American people - are so closely related as to be nearly indistinguishable one from the other." Closer harmony is needed, obviously. Mr. Deutsch suggests that social work would do well to include labor on its administrative boards and give it an active part to play. If private agencies are to do community organization, the boards should be democratic.

Labor should also do its part in regard to its community obligations. It has good reason to have been indifferent to activities other than its own in its early days when full attention was demanded for recruiting and bettering working conditions. At this time, however, the organizations have developed to the point where labor may look outside the factory gate. Adopting resolutions is not enough; more social action could be taken. 1

1

Albert Deutsch, "Get Together, Labor and Social Work," Social Wlork Today, Vo1. IX. No. 5 (April, 1942) p. 13-17 
It would seem that the war would bring labor and soclal work closer together; both are conscious or what is involved in winning the war and the peace as well. Both should plan carefully so that there will be no overlapping of effort, but rather a unity that will make for success. 


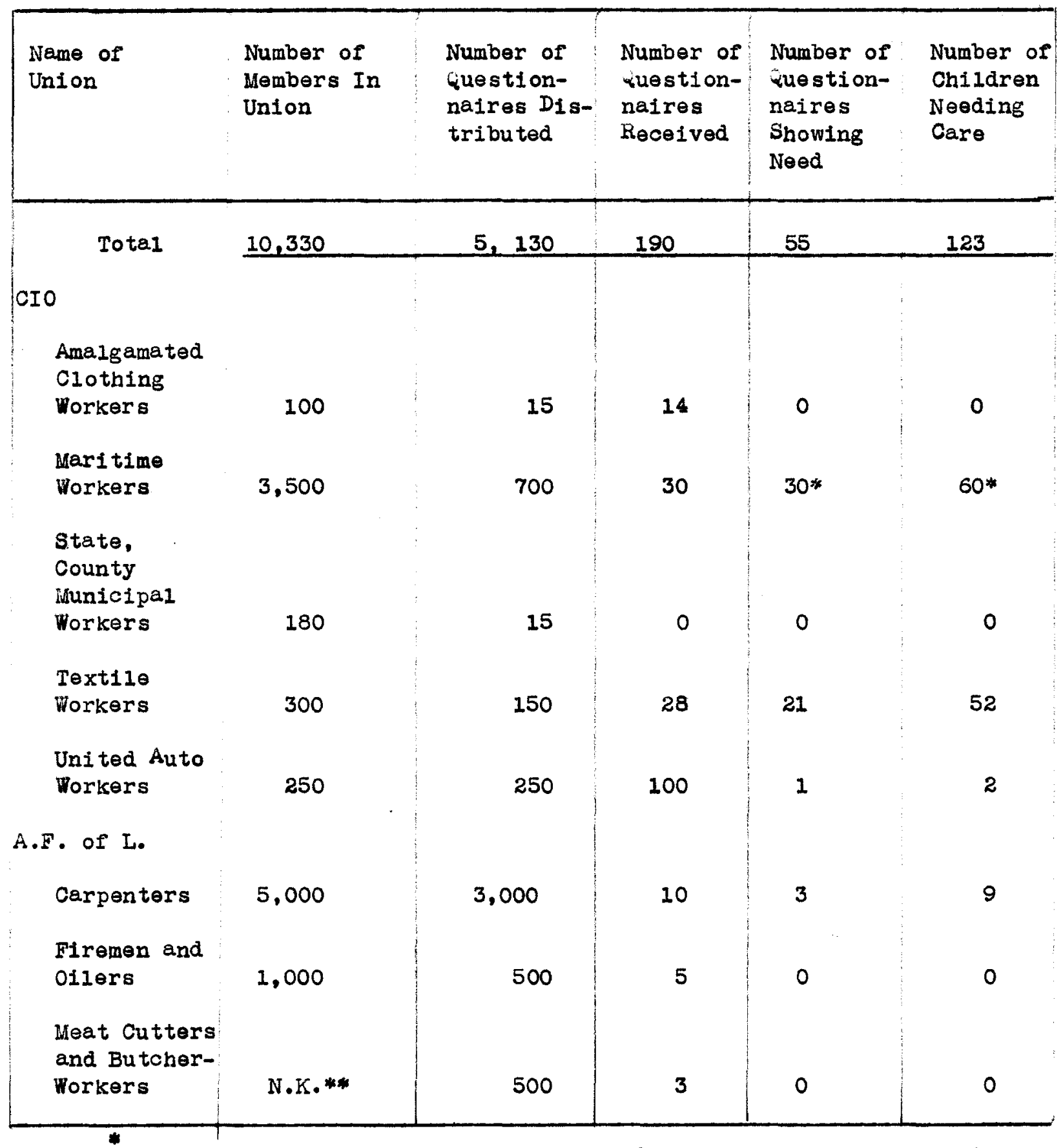

This union lost its questionnaires, and the results are a report given over the telephone by one of the leaders in the union.

**Not known. 
CONCLUSIONS 
Conclusions

I. The term "day care" no longer implies custodial supervision of young children during the time it is necessary for mothers to be away from home. Organized group care of children of pre-school age is only one type of day care service. Care of school age children before and after school, foster family day care service in a private home, the homemaker service and counseling service have been recently included in day care programs. The expansion of the term illustrates greater emphasis on the individual needs of the child and a recognition of the value of cooperation on the part of parents whose ohildren make use of day care service.

II. Present trends in establishing oriteria for day care programs give evidence that the methods of nursery procedure in terms of child training are being recommended for the day nursery. At the same time nursery schools are beginning to extend their hours to approximate those of the day nursery and thus meet the needs of the children of working mothers.

III. The mother of a large family is not performing a patriotic duty when she accepts a full-time war job, particularly if ber children are under fourteen years of age. Too many people are required to take over her duties in the home. There is need for a day center or foster home care for the children under five, a number of teachers and recreation workers to supervise the school age chlldren before and after school, extra workers in the laundries to do her family's washing and possibly someone to take over her shopping. Unless it is necessary for a mother to work because of financial 
need in the family, she performs a greater service in the war effort by staying at home with her children than by entering industry.

IV. The United States may profit from Ingland's experience in providing care for children whose mothers could not be in the home. At the beginning of the war, there was little evidence of long time planning for day care in England with the result that by 1942 the supply of day care services fell short of the demand. Too much responsibility was left to the local authorities. When the extent of the problem was finally realized, it was difficult to secure materials, equipment and personnel. V. There are several indications that the federal government has been cognizant of the inability of communities to supply adequate day care services in the present war emergency. The passage of the Lanham Aot which made possible the appropriation of federal funds to assist communities with day care needs indicates interest in day care on the federal level. The establishment of a day care department in the office of Defense Health and Welfare Services was indicative of an effort to coordinate the work of the federal agencies and thus better serve the communities. In addition, two directives pertaining to the supervision of children of working mothers were issued by the War Manpower Commission. The assumption of public responsibility in allocating funds and establishing criteria for day care programs is significant in Its Implications for the future development of day care. In all probability there will be more uniformity of standards and more efficient administration of existing programs. 
VI. Statistical surveys of the need for day care often fall to show the actual or potential demand for additional services. Many mothers are hesitant to fill in questionnaires regarding the care of their children. They become suspicious of the reasons for the studies and feel a threat to their security when they are asked such questions as, Who cares for the children while you are away from home?"

VII. Day care facilities in Loulsville represent a problem of long standing that reflects lack of community planning. The existing centers, especially those which do not require a fee are not scattered throughout the city but are localized within several neighborhoods. The program for the care of children of Negro mothers, a large number of whom are employed, is inadequate for the number of children needing care. It is probable that many children in the community receive poor supervision due to the fact that it is customary to employ colored malds to care for children in the high and middle income groups: on the lower income level, the children are often left with relatives and nelghbors.

VIII. According to surveys conducted to discover the need for day care in Louisville in 1942 and in the early part of 1943, the demand for additional day care facilities was not as acute as might have been expected from the increase in population due to the present war emergency. The results of the studies indicated that more than five hundred children needed care, however, and application was made for federal funds to establish new centers. Should the request be granted, Louisville will be prepared to meet the situation that may arise in the event more women with children are requested to go into industry. 
RECOMAENDATIONS 


\section{Recommendations}

1. The deciston should be made as to whom the responsibility of financing day care belongs. The fields of education and welfare have been temporarily designated by the federal government: regardiess of the field administering the care, it should be a public service, England recognized the importance of government financing by the passage of the Fisher Aot in 1918.

2. There is a real need for coordination and clarification among the federal agencles concerned with day care, Communities express complete confusion as to methods of application for federal funds which are in constant state of change. There should be more interpretation of the federal agencies' runctions.

3. A national policy should be established by the employment service, the Manpower Commission, and others dealing with the labor supply in regard to the need for women in industry. In this way mothers would have a sounder basis for obtaining employment.

4. Standards that have been achieved in all the areas of day care should be malntained. Continuous re-evaluation of the program should be made.

5. Further study is indicated in areas such as the care of the school age child. In most communities there is a lag between the theory and prectice in the care of children of this age. parent education and participation are essential to the planning and carrying out of day care programs. Only a few nurseries give sufficient time to this phase of the services. The question of fees is one that needs to be investigeted further. 
From all indications the sliding scale is more complicated than a unform rate but it has more meaning in individualizing the service.

6. Increased personnel in day care services will be necessary for the development of adequate programs. More training in nursery procedure should be offered and required. A certificate should be issued upon the completion of a course in nursery school training.

7. Cominunity planning should be an integral part of this system of day care. In Loulsville it would seem advisable to coordinate the efforts of the 10cal Day Care Committee, the Board of Education, and the Child Welfare Division of the Council of Social Agencies, to effect a complete program. Whether or not the federal government may continue to assist comrunities in day care programs after the war may be largely determined by the outcome of wartime day centers experiments. 


\section{APPIINDIX}


Some Ways of Distinguishing a Good Nursery School ${ }^{1}$

1. The school has ample indoor and outdoor space.

2. It malntains safe, sanitary, and hygienlc conditions.

3. It protects and conserves the ohild's health.

4. The sohool provides equipment, play materials that help the ohild's whole body and whole self to grow and develop.

5. There are enough well-trained teachers both to guide group living and to take care of the individual's neods.

6. There are teachers who understand little children and how they grow.

7. The teacher is well adjusted. She realizes that human feelings are lmportant, so she herself expresses feeling and encourages the expression of feeling in children.

8. The child does not become tired of paints, blocks, clay or other constructive materials and is encouraged to use the materials creatively.

9. The school helps children develop wholesome attitudes toward their own bodies and bodily functions.

10. It provides real opportunities for the child's social adjustment.

11. Parents are considered as well as children.

12. The school considers not only what a child does but why he does 1 t.

13. Notes and records are kept on the child's progress.

14. Children are enrolied for day after day attendance.

15. The school's program is set up to consider varying needs of the family.

16. The school does not ignore discipline.

17. Eaoh member of the staff tries to work together.

18. The school works with other groups in the community in order to use all available resources.

1

Compiled from Some Ways of Distinguishing a Good

Nursery Bchool. National Association for Nursery Education and Cleveland Pre-school Standards Committee. Cleveland, Ohio: Cleveland Child Eealth Association, 1939. 
DAY CAEE SURVEY

As more and more women are going to work, many of them are faced with the problem of what to do with their children while they are working. The DAY CARE COMUITTEE of the LOUISVILLE DEFENSE COUNCIL is interested in finding out how many women need help with this problem, so that centers for carlng for the children may be set up. The federal government has set aside runds for this purpose but it will be necessary to gather this information before such funds can be used for Ioulsville. You may be certain that your answers are confidential, and do not obligate you or your family in any way.

1. How many children are there in your family?

2. How old are they? Boys: _ _ _ _ Girls: _ _ _ - -

3. Who takes care of them when you are away?

4. Would you like to have a place where responsible people, able to take care of children, would look after them during the day?

5. During what hours of the day would you like care for your children?

6. Would you be willing to pay something for their care in a child care center?

Name

Address

The work of the Day Care Committee of the Louisville Defense Council has the endorsement of the C.I.O. City Council. (Central Labor Union). 
WOMEN IN INDUSTRY QUESTIONNAIRE

FAMIIX SECURITY COMMITTER

IOUISVILLE DEFENSE COUNCIT

Date

Name of Factory

Address

Person interviewed (Name and titio)

No. of women employed

Wite

Colored

No. of these women with children

With children under 6

With children under 14

Average no. of working hours per day

From

A.M. to

P.M.

No. hours per week

Do women work in shifts?
A. How many shifts and hours each
B. How long on one shift?
C. How many on day shif t?

Average weekly earnings

Do women emplbyees in general live in the neighborhood of plant?

Do you anticipate an increase in the number of women employees during 1942? If so, estimate number 


\section{APPENDIX D}

\section{FAMILY SECURITY COMMITTEH}

LOUISVILLE DEFENSE COUNCIL

¿uestionnaire - Day Care for Children of Working Mothers

Some mothers who are working have requested information regarding nursery or boarding home care for their children. The Family Security Committee of the Louisville Defense Council is interested in determining the number of mothers who might need these types of care for their children. If you will please answer the following questions it will be helpful to the committes in their effort to make nursery or boarding home care available, where it is needed in the City.

WILL YOU FILI IN THE FOLLOWING INFORMATION AND RETURN THIS FORM?

Name of firm where you are employed

Your name

Your Address

What kind of work do you do? How long employed?

If you have children please list for each child:

Boys:

Name

Age

Girls:

Name Age

How are your children being cared for at the present time?

By person employed by you?

By relatives?

By friends or neighbors?

In a day nursery?

In a boarding home for day care?

In a boarding home for day and night care?

Are you satisfied with the care your children are having while you are working?

Yes No

If not, do you want help in planning for your children's care? Yes No

During what hours during the day or night do you need care for your children? 
The purpose of this questionnaire is to obtain a list of names of employees interested in obtaining suitable and reliable places, centrally located, where they may leave their children durling working hours, namely day nurseries. The success of obtaining this service, if possible to obtain, will depend largely on your interest and cooperation in filling out this blank.

1. Name
2. Address
3. Hours worked and shift
4. Number of children 2 years old and over
Boys Girls
5. Ages of children 2 years or over
Boys Wirls
6. What hours would you use in this service
7. Do you have the means of taking and picking up your
8. Have you ever used this type of service? Yes_ No
9. Have you ever been absent from work because of the
10. Woed for this service? Yes. Would you be able to pay a nominal charge for this
11. Service? Yes

Please return this to a member of the War Production Drive Committee or to your supervisor as soon as possible.

War Production Drive Committee

Hoosier Ordnance Plant 
Project No.

(Not to be filled in by applicant)

APPLICATION FOR A CONTRIBUTION FOR MAINTENANCE AND OPERATION OF COMUUNITY FACILITIES

The applicant named below applies for an allotment of Federal funds in the amount of $\$$ as a contribution for the maintenance and operation of its facilities, located at

for the fiscal year, beginning 194

The Applicant is of the opinion that there exists or impends in such locality an acute shortage of public service comprising the maintenance and operation of facilities necessary to the health, safety, or welfare of persons engaged in national-derense activities which would impede national-defense activities, and that such public service cannot be provided when needed, or could not be provided without the imposition of an increased excessive tax burden or an unusual or excessive increase in the Applicant's debt limit.

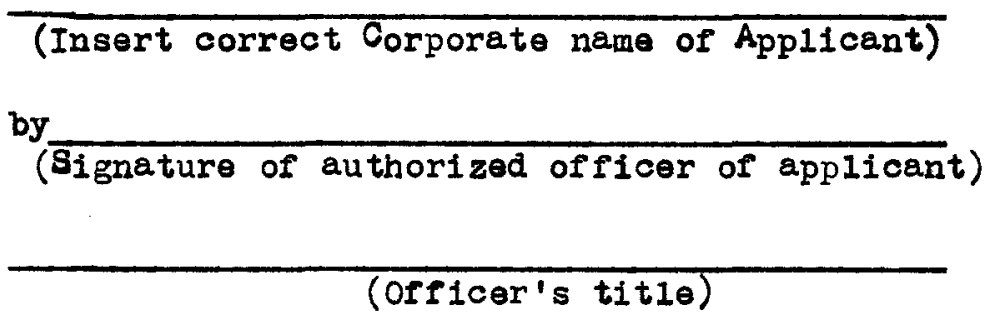


- THE AFFIANT, being first

duly sworn, says:

1. That the Affiant has been authorized by the above-named Applicant to execute and submit this application, and,

2. That the information contained herein is true, correct, and complete to the best of his knowledge and belief.

(Signature of Affiant)

Sworn to before me this

day of 194

(Title)

My Commission expires 194

The Applicant should answer each question fully. See Section statement of Policy and Procedure. If the Information requested is not avail$a b 1 e$, it should be so stated. The data furnished must be complete and accurate. Additional information may be supplied, if desired, by attaching adequate exhibits which should be numbered and referred to by such number in the appropriate paragraph of the application.

I. Description of service or assistance needed

(a) Type of service or assistance covered

(b) Geographical area and scope of service

(c) Bxtent or Service, such as persons served

(d) Existing facilities for this service 
II. Legal authority of Applicant

(a) Constitutional and Statutory provisions under which Applicant has been created or organized

(b) Classification and type of community or agency (Where pertinent)

(c) Authority for maintenance of service

1. Constitutional provision

2. Statutory provision

(d) Are there any sections of the oonstitution, statutes or charter which would prevent the Applicant's accepting or disbursing a contribution for maintenance and operation of the facilities?

If the answer is "yes" give specific statutory references

III. War justiflcation

(a) Population 1930 1940 Present estimated

(b) State concisely the extent of war activities in the community Indicating the effect of such activities upon operation of facilities.

(c) Indicate manner war effort is impeded by lack of, or insufficient service.

(d) If any portion of the requested contribution is to be used for the maintenance and operation of any facilities which are being or are to be constructed or otherwise provided, give full details indicating when such facilities will be ready for operation

IV. Financial justification

(a) Attach comparative statements for past three fiscal years covering

1. Expenditures for maintenance and operation of facility by major classifications of cost

2. Income from all sources (including Federa1, State, and other assistance) 
IV. Financial justification (continued)

(b) Attach schedules of tax for the past three years

(c) Indicate changes in total assessed valuation

(d) Estimated expenditures for period requested to provide needed services

(e) Estimated income -. all sources contributing to services

Include any additional fiscal information supporting the applicant's claim of insufficient financial resources to proper $1 \mathrm{y}$ provide needed services.

(f) Indicate substantial changes

V. Review Recommendations and Approvals

(A) State Clearance Agency

$$
\text { (Name of Agency) }
$$

Date

$$
\text { (Signature) (Tit1e) }
$$

(B) State Service Director

$$
\text { (Signature) }
$$

Date Comments

(C) Regional Review Board Recommendation

Regional Director

\section{(Signature)}

Date.

(D) Central office Action Reoommended

Assiatant to the Administrator Date 
VI. CERTIFICATE OF NEED OR NECESSITY

Project No.

Brief description of service

Name of applicant

This certifies that we have examined the foregoing application and concur in the need for the war public services requested in the area outlined for a Federal contribution to the applicant under the Lanham Act.

\section{(Agency)}

(Date)

(Signature and $\mathrm{Title}$ ) 


\section{APPENDIX G}

STATEMPNT OF ASSESSED VALUATION

(From annual reports)

\begin{tabular}{l|l|l|l|l}
\hline \multirow{2}{*}{ Assessments } & \multicolumn{2}{|c|}{$\begin{array}{l}\text { Actual figures for three fiscal years } \\
\text { next preceding the ourrent year }\end{array}$} & $\begin{array}{l}\text { Estimate } \\
\text { for current } \\
\text { year }\end{array}$ \\
\cline { 2 - 5 } & Third year & Second year & First year & \\
\hline & & & & \\
\hline
\end{tabular}

Total

DISTRIBUTION OF TAX RATE

(From annual reports)

\begin{tabular}{l|l|l|l|l}
\hline $\begin{array}{l}\text { Departments } \\
\text { and } \\
\text { Establishments }\end{array}$ & \multicolumn{2}{|c|}{$\begin{array}{c}\text { Actual figures for three fiscal years } \\
\text { next preceding the current year }\end{array}$} & $\begin{array}{c}\text { Estimate } \\
\text { for current } \\
\text { year }\end{array}$ \\
\hline & Third Year & Becond Year & First Year & \\
& & & & \\
& & & &
\end{tabular}


DETAIIAD EXPINDITURES FOR

(From Annual Reports)

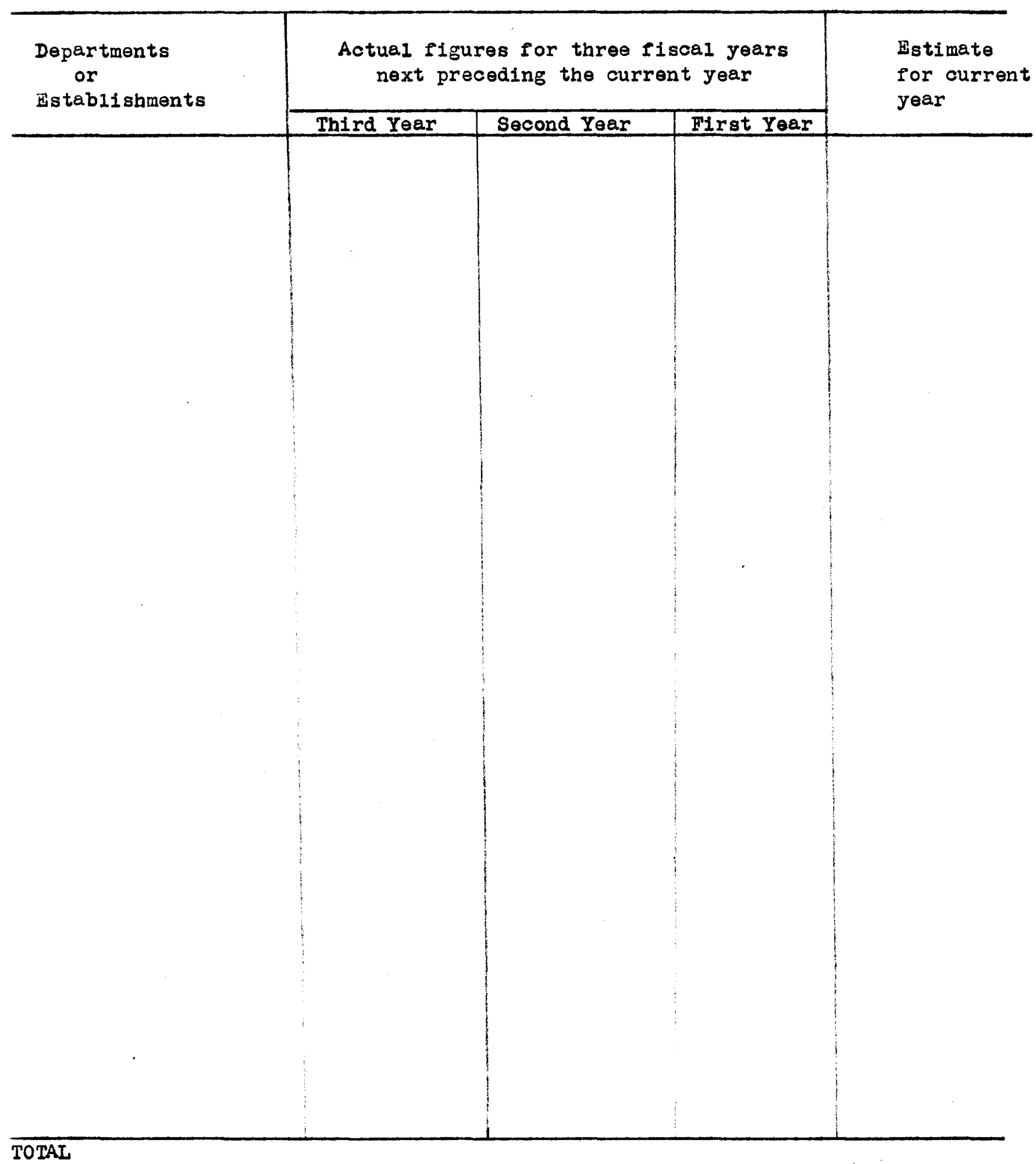


INCOME FROM ALI SOURCES

(From Annual Reports)

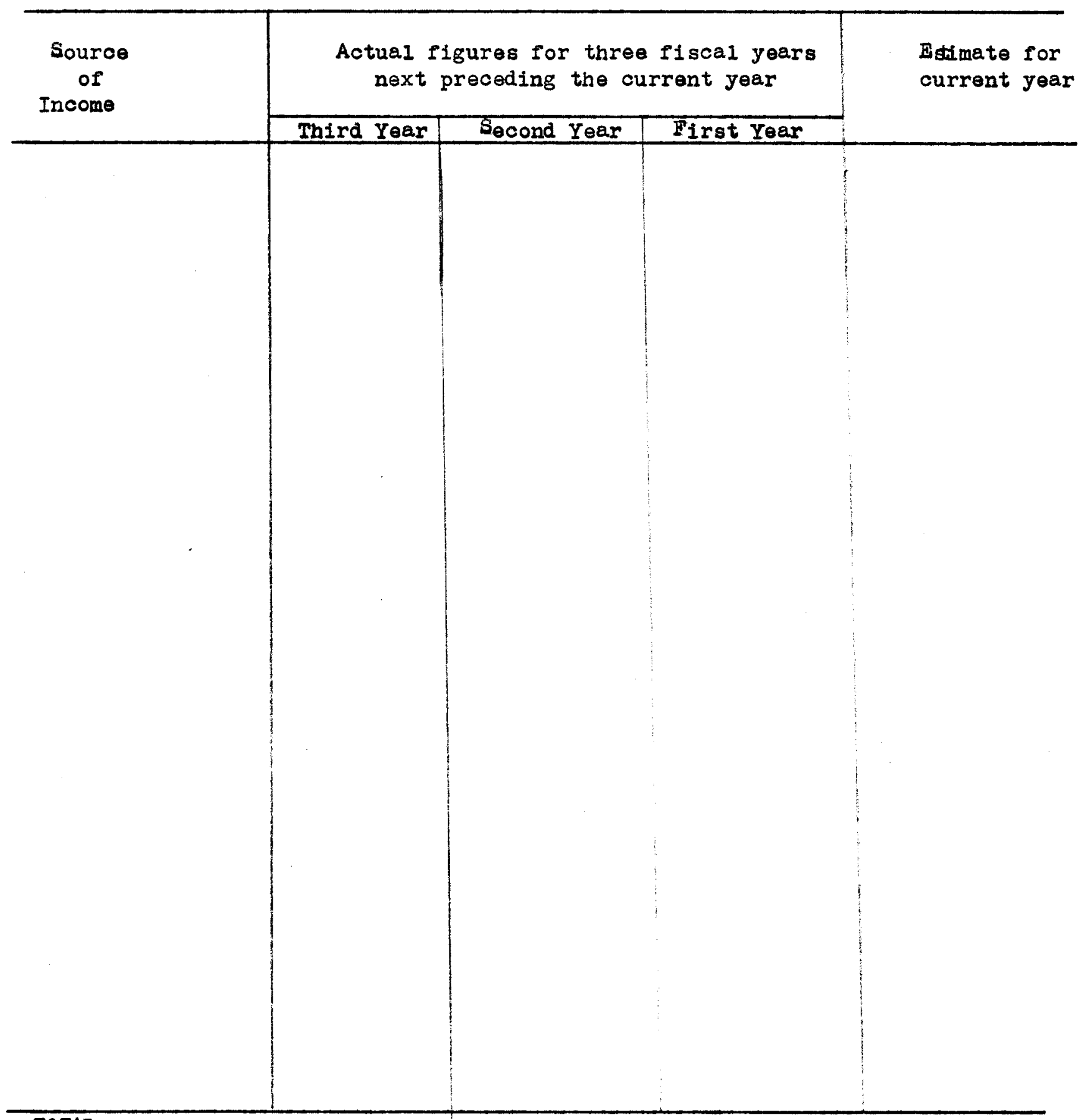


EXPENDITURES FOR AIL PURPOSES

(From Annual Reports)

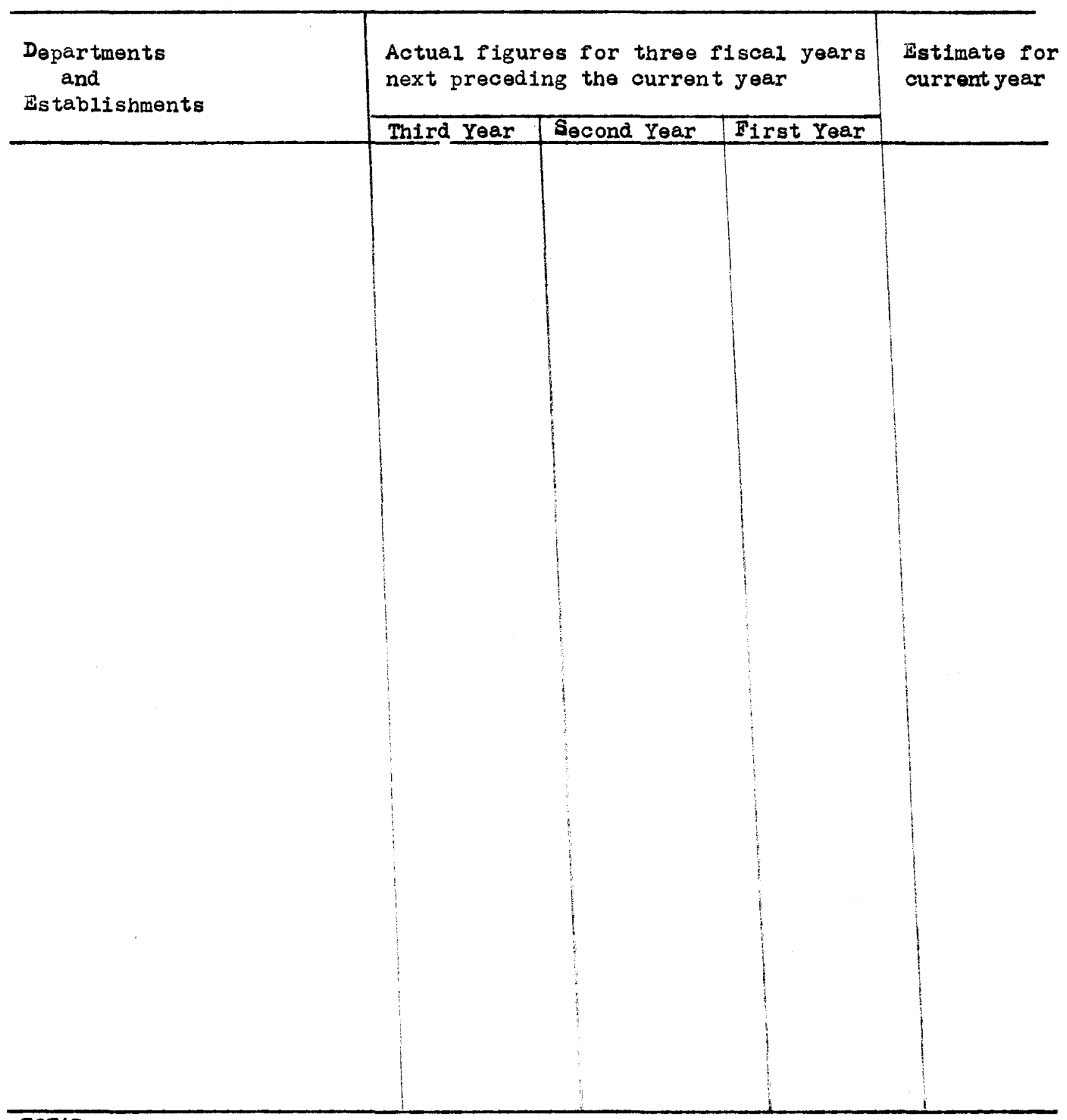

TOTAL 
DETAILED STATEMIENT

OF

PURPOSES FOR WHICH REQUESTHD FUNDS

WILL BE EXPENDED 
JUSTIFTCATION OF REQUEST FOR

FEDERAL FUNDS 
BIBLIOGRAPHY 


\section{BIBLIOGRAPHY}

Books

Beer, Ethel S. The Day Nursery. New York: E. P. Dutton and Co., Ino., 1942 .

Forest, I180.The Child from Two to Eight. New York: Ginn and Co.., 1935 .

Foster, Josephine C. and Mattson, Marion L. Nursery School Procedure, New York: D. Appleton and Co. 1929

Moll11an, Margaret, The Nursery School. London: Dent Publishing Co. 1919 .

Nursery iducation. Wite House Conference on Child Health and Protection. New York: The Century Co. 1931

Owen, Grace. Nursery School Education. New York: Henry Holt and $C_{0} .1920$.

\section{Reports and Pamphlets}

Child Care Programs, A Report of the Child Care Committes of the Defense Counc11, Connecticut State Department of Education, Hartford, Conn. May, 1942.

Field, Marshall, The Relationship Between Problems of Chilaren and the Problems of Manpower Reprint of an Address Given at the Delaware White House Conference on Children in a Democracy. Nilmington, Delaware, November 18, 1942.

Proceedings of Conference on Day Care of Children of Working Mothers. Washington: U. B. Government Printing office, 1942 .

Report of the Committee on Day Care, Hartford Coumeil of Social Agencies, August, 1941, 12 pp.

Btandards for Day Care of Children of Working Mothers, Washington: U. S. Department of Labor, Children's Bureau, 1942.

Standards for Day Nurseries in California, State of California, Department of Social Welfare. 1942. 


\section{Articles}

Alzen, Grace T., Davis, Maxine and Olivier, Warner MightHour Orphans," Saturday Evening Post, October 10 , 1942, pp. 20, 21, 105, 106.

Bach, Mildred P. "The Application Interview," The Day Nursery, March, $1940 \mathrm{pp}$. 44-6

Benjamin, Thelma H. "English Day Nurseries," The Day Nursery, January, $1942 \mathrm{pp} \cdot 11-13$

"Britain Meets Problem," Newsweek, XX, No. 26 (December 28, 1942) p. 38 .

Ba1r. Amelia and Fast, Jane, "Some Problems of Working Mothers," The Family, February, 1943, p. 387 .

Bingham, Mary Caperton "Home Front 'Tlar Orphans' Mustn't Be Neglected," Louisvilie Courier-Journal, October 15, 1942 .

Black, Irma S. "Defend Them From Fear," The Day Nursery, December, 1941, pp. 11, 12.

"Children Bear the Promlse of a Better Dorld - Are Me Safoguarding Those Whose Mothers Work?" Derense of Children Series No. 2, 1942.

"Children in wartime: The Under-Fives, "Bulletins from Britain No. 84, April 8, 1942 .

"Oity to Ask U. S. Ald for Day Nurseries," Louisville CourierJournal, October 28,1942 .

Clark, Blizabeth Woodruff "We Enlist for Defense," The Day Nursery, September, 1941, pp. 7-15

Clark, Elizabeth Woodruff, "A Challenge to Case Work," The Fanily January, 1942, p. 291

C10se, Kathryn "Wile Mothers Work," Survey Midmonthly, July 1942, pp. 196-198

"Committee Recommended to Ask Federal Funds for Day Nurseries Here," Louigville Courier-Journal, October 7, 1942

Cull1s, Winifred C. "Nurseries Free Mothers for War Work," Bulletins from Britain, No. 79, March, 1942. 
Davies, Stanley P. "The Dey Nursery Looks Ahead," The Day Nursery, January, 1940.

"Day Nurseries," People in Production, Mass Observation Report for Advertising Bervice Guild. London: John Murray Co., 1942, pp. 178-187.

Deutsch, Albert, "Get Together, Labor and Social Work," Social Work Today, IX (April, 1942), pp. 13-17

Du Pont, Fthel 8. "U.S. Funds for Dhy Nurseries Depend on Survey," from the column, "With Labor's Ranks" in the Louisville Times, October $2,1942$.

"Margency Child Care Programs - With Special Reference to Care of Children of Working Mothers." Connecticut State Department of Education, Hartford, Conn. 1942.

"Extended Sohool Services for Children of Working Mothers," ducation for V1ctory, I, No. 14 (September 15, 1942) pp. $1-3$

"P1rst Lady Sees British Nurseries," Louisvilie Courler-Journal October 4, 1942 .

Franklin, Adele, "The School's Open Door," The Day Nursery, January, 1942 , pp. $7,8,9$.

" Free Labor W111 W1n,' Bay Women Workers," Loulsvilie CourierJournal, Ootober 18, 1942.

Gordon, Henriette "Impact of National Defense on Child Melfare," "The Femily" March, 1942, p. 3

Guyler, Catbryn S. "Social Work Responsibility for the Development of Day Care," Proceedings, National Conference of Social Work, 1942.

Hamill, Urs. Laurence "Day Care in Cleveland," The Day Nursery (December, 1942) pp. 7-9

IRR 4545 Congressional Record, Vo1. 87, Part IV, Washington, U. S. Government Printing office, 1941.

Hughes, Therle "Bevin Belles: Nartime Specialists," Survey Graphic, July, 1942, pp. 324-327 
Hutchkins, Dorothy, "Spotilght on Day Nurseries," The Dey Nursery, Apri1, 1942, p. 1

Jeter, Helen, "Wartime Problems of Family Security," The Family May, 1942, p. 83

Joiner, M. A., and Weiner C., "Imployment of Women in War Production," Social Security Bulletin, V., No. 7, (July, 1942) pp.4-16

Kuttner, Bess "The Housekeeper Service," The Day Nursery February 1941, pp. 5, 6, 13.

Loomis, A.K. "Nursery School Aide Training," Education for Victory, June 1, 1941.

Lundberg, Ima 0. "Ascertaining Day-Care Needs of Chilaren of Norking Mothers," Reprint from The Child, VII, No. 1 Ju1y, 1942, pp.6-8

- "Counseling Service in a Day-Care Program," Reprint from The Child , VII, No. 3, September, 1942, pp. 31-34.

- "Factors in Planning Community Day Care Programs." Reprint from The Child, IX, No. 11, May, 1942, pp. 281-285

MaElroy, "Wartime Need for Day Care of Children," The Family, June, 1942 , p. 123

Moore, John H. "A Community Plans for Day Care," The Day Nursery December, 1942, pp. 1,12,13,14,15.

"Parents' Fee for Day Care," The Day Nursery, December, 1942, p. 9.

Pearson, Gereld E. J. "Cooperation Between the Day Nursery Worker and the Psychiatrist," The Family, January, 1942, p. 309

Simon, Iady E. D. "The Working Mother in England," The Child, VII, No. 5, November, 1942, pp. 62-64

"A Suggested Plan for the Care of Children of Mothers Fmployed In Defense Industries, San Francisco, 1942. (mimeographed).

Volland, Alice, "Case Work in a Day Nursery," The Family, May 1942, p. 97

Washington Conference, The Day Nursery, December, 1942, pp. 5-7

"Day Care Board Seeks Advice From Union Workers" Kentucky Labor Newe October 1, 1942. 


\section{Unpublishod Material}

"Broadcast on War Nurseries and Day Care of Children," Federal Works' Agency, August, 1942.

"Ohlldren's Services," Federal Works Agency, Washington, September, 1942 .

"Counseling Service to Mothers Going to Work," FWAA B1ue Bulletin, Series B \#6, February 26, 1942.

"The Day Care Program of the Pederal Government," office of Defense, Health and Welfare Services, July 27, 1942 .

"Employment in Industry of "omen with Young Children," FWAA Blue Bulletin, Series C. \#3, September 24, 1942.

"Experiment in Foster Day Care," Report of the Cleveland Day Nursery Association, 1940.

"Extended School Services for the Children of the Working Mothers - Mducation's Part in the Program," U. S. Office of Bducation, October 21, 1942.

Lawson, Marianna, "Study of 28 Working Mothers," Unpublished Master's thesis, Graduate Division of Social Administration, Uhiversity of Louisville, 1943.

"Operation of Day Nurseries and Nursery Schools for Children of Imployed Mothers, "Federal Works Agency, Commissioner's Letter No. 68, July 28, 1942, and the Service Letter No. 6. April 21, 1942.

Phelps, Katherine Dew. "Foster Day Care," - Based on Two Years" Bxperience of the Montclair Day Nursery. May 1942, pp.10.

"Policy on Imployment in Industry of Women with Young Children," War Manpower Commission, August 12, 1942.

"Procedure and Requirements for Day Care Projects under the Community Facilities Act," FWAA Blue Bulletin, Serles $B$, \#12, yay 15,1942

"To Certain Government Departments and Agencies, to Develop, Integrate and Coordinate Federal Programs for the Day-Care of Children of Working Mothers," Mar Manpower Commission Directive No. IX, August 12, 1942. 